\title{
Las «nuevas meninas» o «bienvenido Foucault». Performance - Escenificación - Transmedialidad - Percepción - Frida Kahlo - Diario - Fotografía - Pintura
}

The New Meninas or «welcome Foucault»Performance - Escenification - Transmediality perception - Frida Kahlo - Diary - Photography Painting

\author{
Alfonso de Toro \\ Centro de Investigación Iberoamericana, Universidad de Leipzig, Alemania \\ sekretariatdetoro@rz.uni-leipzig.de
}

Resumen - Kahlo elabora y desarrolla diversos procedimientos performativos que contribuyen a superar la idea de que arte es solamente aquello duradero, elitista, museal, comercial. Kahlo es una pionera de la performance, de un concepto vidaarte-cuerpo/arte-cuerpo-vida, ella es su propio medio, artefacto, presentación y producto, es arte-objeto, arte-acción y creadora de un nuevo realismo y de lo que más tarde se va a llamar body-art, happening o fluxus.

Palabras clave: fotografía, pintura, performance, artefacto, arte-objeto, arte-acción, body-art, happening, fluxus.

\begin{abstract}
Kahlo work out and develop diverse performative strategies that contribute to overcome the idea that art is only that what is durable and sublime, elitist, that belong to a museum and it is commercial. Kahlo is the pioneer of the art form performace, she creates a new concept of life-art-body/art-body-life, she is her own medium, artefact, presentation and product, she is art-object, art-action, she founds a new realism and that what later is going to be called body-art, happening or fluxus.
\end{abstract}

Key words: Photography, painting, performance, artefact, art-object, art-action, body-art, happening, fluxus. 
El propósito de mi trabajo hoy — que continúa el de aquel publicado en 2008- es, por una parte, describir el sistema semiótico de la producción de Kahlo y de las fotografías que se le hicieron y, por otra, demostrar cómo no era tan sólo una pintora, sino que a su vez era una artista performativa que usaba su propio cuerpo como objeto artístico en su vida cotidiana y en sus intervenciones en la vida pública. Kahlo es una de las primeras personalidades artísticas que se mediatiza en forma absoluta, ya sea en su Diario, en su pintura o en las fotografías o eventos sociales. Es un concepto vida-arte-cuerpo, artecuerpo-vida. Kahlo es siempre su propio medio, artefacto, presentación y producto.

Quisiera comenzar citando a Carlos Fuentes, quien, a pesar de su interpretación con rasgos marcadamente biográficos, hace un aporte notable a algunos aspectos del «sistema Kahlo» como sistema mediático en la «Introducción» al Diario. Fuentes apunta a la auto-escenificación de Kahlo en sus apariciones públicas, tanto ópticas como sonoras:

Cuento todo esto sólo para decir que cuando Frida Kahlo entró a su palco en el teatro, todas las distracciones musicales, arquitectónicas y pictóricas quedaron abolidas. El rumor, estruendo y ritmo de las joyas portadas por Frida ahogaron los de la orquesta, pero algo más que el mero sonido nos obligó a todos a mirar hacia arriba y descubrir a la aparición que se anunciaba a sí misma con el latido increíble de ritmos metálicos, para en seguida exhibir a la mujer, que tanto el rumor de las joyas como un magnetismo silencioso, anunciaban (7).

La cita anterior pone en evidencia la escenificación pública de Frida Kahlo que conlleva caracteres fundamentalmente mediáticos. Los términos «teatro»/«exhibir», «rumor»/«estruendo», «ritmo», «joyas», «latido» apuntan a elementos mediales de la «acción», de lo "acústico», del «vestuario», conformando una escenografía que cautiva al espectador y que percibe a Kahlo como una "aparición». Ese movimiento es lo que constituye la performance, el happening, el arte-acción, el arte-cuerpo de Kahlo.

Schwan agrega, en forma crítica a un tipo de acercamiento mitizante y mistificante como el de Carlos Fuentes:

La Frida del siglo XXI es tanto una estrella — una mercancía con su club de admiradorescomo a la vez también un icono de las esperanzas y expectativas de una comunidad de seguidores con características casi religiosas. Esa recalcitrante e híbrida Frida, una mezcla de Virgen de Guadalupe, bohemia trágica, heroína revolucionaria y Salma Hayek, ha encubierto entretanto su imagen pública de tal forma que la figura histórica de Kahlo está amenazada por ser encubierta (6; mi traducción).

Mas, Fuentes mismo relativiza dicha tendencia autobiografizante cuando apunta que:

Kahlo fue más, mucho más que todo esto, [como] lo demuestra ahora su Diario. Nos muestra su alegría, su sentido del humor, su imaginación más fantástica. El Diario es su línea de cabotaje con el mundo. Cuando Frida se vio, se pintó; y se pintó porque se sentía sola y porque era el sujeto que mejor conocía. Pero cuando Frida vio el mundo, escribió, paradójicamente, un Diario pintado gracias al cual nos enteramos de que, a pesar de la interioridad de su arte, éste siempre fue un arte maravillosamente cercano al mundo material de animales, frutas, plantas, tierras, cielos (10).

Con su procedimiento performativo, Kahlo contribuye a superar la idea de que arte es solamente aquello duradero, elitista, museal, comercial y que se encuentra por lo general en las artes plásticas. Kahlo es, además, una pionera de la performance y del «arte-obje- 
to»(Objektkunst), del arte-acción (Aktionskunst) y de lo que a partir del 27 de octubre de 1960 se llamará el «Nouveau Réalisme», que tenía como finalidad romper con el estatus de lo sublime en el arte, pero no por la vía de lo abstracto, sino tomando técnicas y materiales de la vida cotidiana e integrándolos en el arte, que luego llevará a la formación de los mencionados arte-objeto y arte-acción, en particular al body-art y al happening.

Y quisiera, antes de proseguir, recordar qué significan algunos de esos términos y procesos artísticos que se producen con Yves Klein en los años cuarenta en Francia y a fines de los cincuenta en particular en EE.UU. y que Kahlo ya introduce a partir de los treinta. No obstante, mi interés no es demostrar que Kahlo fue la pionera de esos tipos de arte, sino describir sus prácticas performativas.

Por el concepto de performance generalmente se entiende un acto artístico ligado a un espacio cualquiera y que se puede dar en cualquier momento y sin una duración determinada. Cuatro elementos constituyen la performance: el tiempo, el espacio, el cuerpo del artista y una relación particular entre artista y espectador. La escenificación de la performance puede ser prefigurada según un plan determinado o puede ser abierta, pasando a ser la contingencia de su desarrollo un elemento central de ella. Si entendemos performance como acto contingente y conectado con el cuerpo de una determinada persona o grupo de personas, con el espacio y con una situación determinada, la mismo no es repetible en exacta forma, pues cada acto por similar que sea conlleva la diferencia. Particularmente en Kahlo tenemos una epistemología de la repetición y de la diferencia. El acto performativo tiene diversos medios, puede ser el filme o el video, y en el caso de ella y en el material aquí analizado, la fotografía, conllevan el riesgo de la comercialización y del fetichismo con un carácter irónico o provocador, que puede pasar a ser reliquia (exvoto) o un souvenir. Kahlo resiste a lo efímero de la escenificación performativa con la repetición y con una constante interacción entre actuación-en-vida, su traspaso a la fotografía y a la pintura. De esa forma, Kahlo anticipa también aquello que Marina Abramovic va a formular el 2005 en su performance serial de Seven Easy Pieces: al contrario del principio tradicional de que por estar el acto performativo ligado al cuerpo del artista ese acto es irrepetible, y de allí que el artista moderno deba enfrentarse al fenómeno de la repetición para estudiar la posibilidad de conservar el saber y la memoria cultural en un medio por principio efímero. En el caso de Kahlo la estabilización de la performancia no es naturalmente una respuesta al mundo cada vez más digitalizado y por ello efímero, que no estaba presente en su época, sino para la construcción de diversas y múltiples identidades culturales y para la construcción de un proceso artístico (Kunsthaftigkeit).

Por su parte el concepto de happening en su sentido tradicional quería, en principio, ampliar el concepto de arte canónico y entrelazar el arte con la vida cotidiana. Acciones individuales serían abstraídas como casos ejemplares. Y ése es también precisamente el caso de Kahlo, que se presenta en actos cotidianos pero que luego son ritualizados y elevados al estatus de arte a través de la repetición.

En todos esos conceptos el cuerpo tiene el papel primordial que nuevamente encuentra su máxima expresión en los años sesenta en el body-art (Körperkunst), relacionado además con el movimiento happening y el movimiento fluxus. Aquí, como ya antes en Kahlo, el cuerpo sirve como un medium artístico, es artefacto y mensaje a la vez y sus géneros principales son performances, la fotografía y el video. Los artistas se producen heridas y dolor: el cuerpo como material. Me refiero aquí a artistas del body-art como Vito Acconci, Denis Oppenheim, Gina Pane, Michel Journiac, Urs Lüthi, Rudolf Schwarzkogler 
y Marina Abramovic, y a representantes del «accionismo vienés». Uno de los efectos del body-art a fines de los años sesenta es atacar al público, provocarle un shock y efectos repugnantes. Mucho de ello tenemos en las pinturas de Kahlo, tales como «un objet qui fût immédiatement pénétrée de désir, de repulsión, de nostalgie, d'euphorie» (Barthes, La chambre, 41), el asco o la convulsión, por ejemplo, en "Sin esperanza» o de «Unos cuantos piquetitios», "Hospital Henry Ford» o «Mi nacimiento»:

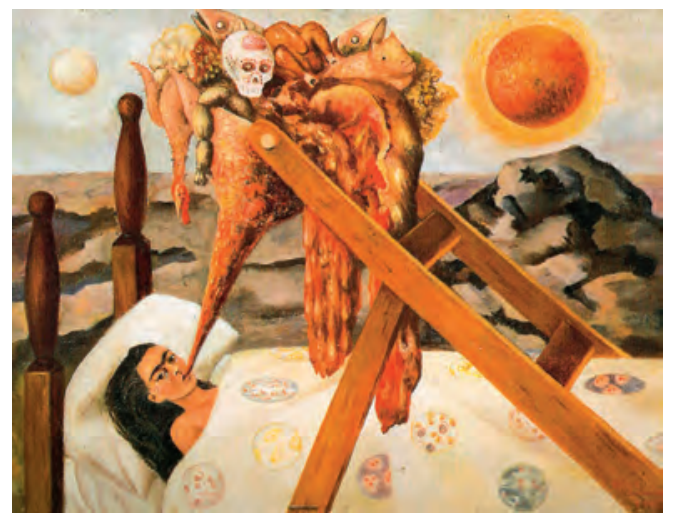

Imagen 1

(de F.K.: Sin esperanza 1945)

(c) VG Bild-Kunst, Bonn 2011

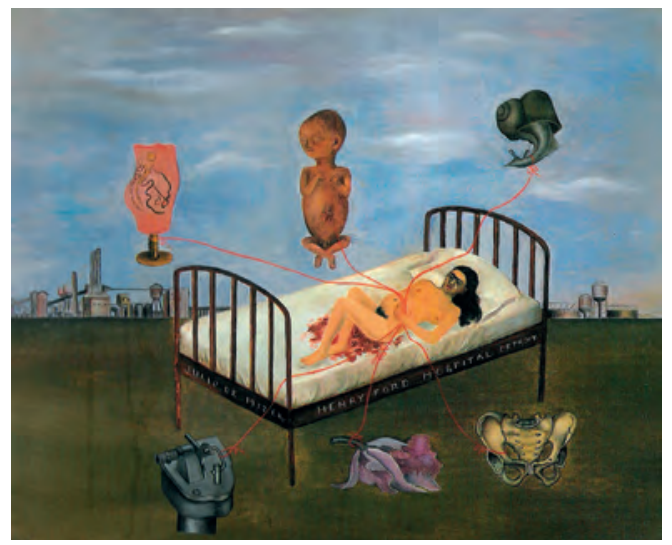

Imagen 3

(de F.K.: Hospital Henry Ford 1932)

(c) VG Bild-Kunst, Bonn 2011

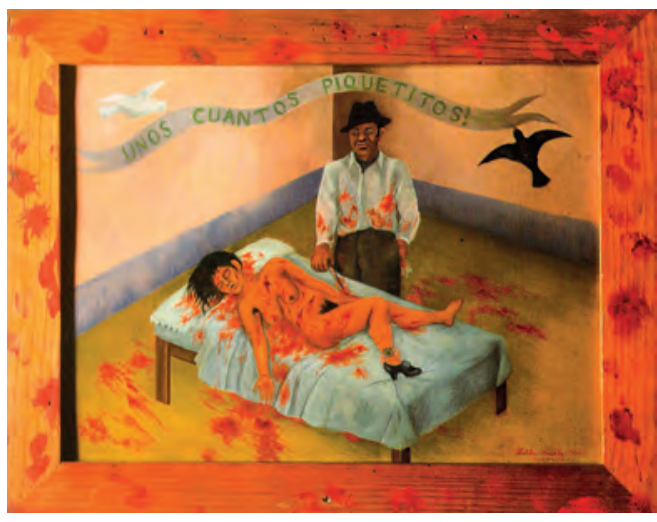

Imagen 2

(de F.K.: Unos cuantos piquetitos 1935-1936) (c) VG Bild-Kunst, Bonn 2011

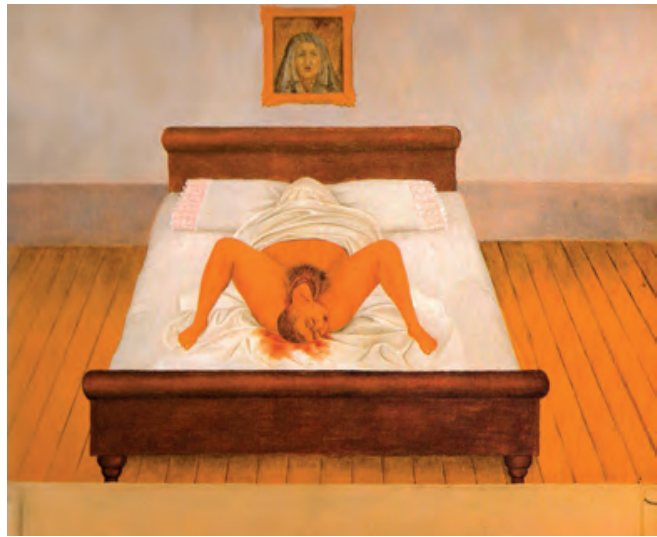

Imagen 4

(de F.K.: Mi nacimiento 1932)

c) VG Bild-Kunst, Bonn 2011

En los años setenta se suma la exigencia de la experiencia corporal como un imperativo político, como lo plantea François Pluchart en su Manifiesto. El término fluxus (del latín flux/fluere = fluir) aparece en 1960 como título de una revista, Fluxus Preview Review, que edita el artista George Maciunas con el galerista Almus Salcius. 
A continuación quisiéramos describir algunas de las estrategias de escenificación y de performance en la obra de Kahlo, sobre la base de cuatro aspectos: elementos del Diario de Frida, la fotografía en relación con la pintura y con la serialidad, repetición y diferencia en su pintura, la transpictoralidad y finalmente la metapicturalidad.

\section{ESCENIFICACIÓN Y PERFORMANCIA: EL DIARIO}

El Diario de Frida Kahlo representa uno de los mejores ejemplos de escenificación y performancia y pone con ello en evidencia su carácter público, que quisiera demostrar basándome en la primera página e imagen «Pinté de 1916», y que ya ha sido objeto de mi análisis e interpretación (cfr. De Toro, «Frida Kahlo»), por lo que me concentraré tan sólo en los aspectos mediáticos.

En su Diario, Kahlo declara tener seis años en 1916 y así haber nacido en el año de la Revolución Mexicana, en 1910. Segundo, Kahlo provoca la impresión frente al lector que abre el Diario y lee esa fecha como primer dato cronológico de que la escritura del Diario comienza en 1916 y no en 1944, como sucede realmente, abarcando los últimos diez años de su vida. Así, Kahlo se escenifica además como niña prodigio de una alta reflexividad y dotes artísticas. La manifiesta escenificación es evidente, ya que un tal truco cronológico con las implicaciones indicadas no tiene ningún sentido para sí misma: Kahlo no tiene que convencerse a sí misma del truco, sabe que es un truco y por ello semejantes estrategias están dirigidas al lector o al espectador:

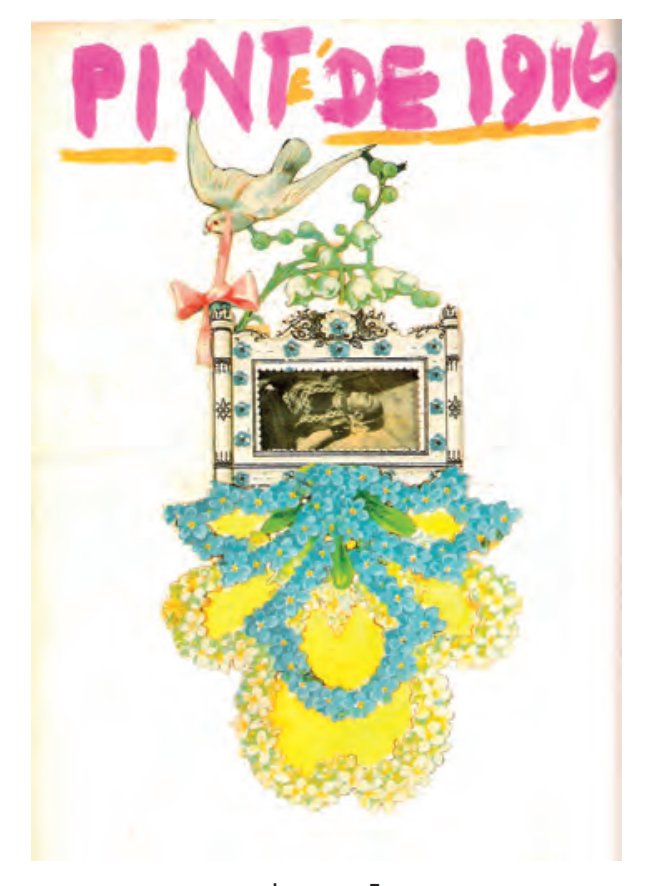

Imagen 5

(Diario de Frida Kahlo, 1916) @ VG Bild-Kunst, Bonn 2011 
Con esa construcción, Kahlo hace de sí misma un artefacto, lo que además del aspecto cronológico queda claro en la fotografía donde ella como adulta se encuentra en su cama. Hay, pues, un quiebre cronológico, por una parte la niña de seis años acotada con la fecha de 1916, y por otra la mujer mayor postrada en su lecho como consecuencia de su accidente. Así, Kahlo desenmascara lo expuesto como una construcción. El hecho de que ella esté en el centro como objeto, la transforma en esta representación como una performancia, vía fotografía y montaje.

La fotografía conserva el momento de la acción performativa, la congela y la pone en circulación como una repetición de cada acto de la mirada del espectador-lector. Por otra parte, la repetición reemplaza lo vivo de la acción, la pone en movimiento y cada diferencia es un indicador de ese movimiento, como lo podremos observar en algunas de las siguientes foto-imágenes-pinturas por tratar.

Esa ambigüedad y tensión entre diferencia y repetición o entre identidad y diversidad de identidades o no-identidades la queremos situar y contextualizar en la epistemología de la diferencia y repetición de proveniencia deleuziana en relación con Heidegger. El fenómeno se encuentra en todos los campos, tanto en la literatura, en el inconsciente, como en la lengua y particularmente en el arte (cfr. Deleuze, Différence, 1). Aquí la diferencia y la repetición han tomado el lugar de la identidad y de su parte negativa, de la identidad propiamente tal y de su contradicción (Différence, 1).

Según Deleuze, la diferencia no implica precisamente la negación, sino que se deja tan sólo llevar a la contradicción en cuanto se continúe subordinándola a la identidad. A pesar de que la identidad define el mundo de la representación, ésta nace en el pensamiento moderno del fracaso de la representación, representa la pérdida de la identidad y a la vez el descubrimiento de todas las fuerzas que actúan bajo la representación. Y por ello Deleuze afirma que: «[...] le monde moderne est celui des simulacres. L'homme n'y suivi pas à Dieu, l'identité du sujet ne suivi à celle de la substance. Toute les identités ne sont que simulée, produites comme un "effet» optique, par un jeu plus profond qui est celui de la différence et de la répétition» (Différence, 1 ).

Importante en nuestro contexto es que Deleuze, por una parte, acentúa la autonomía de la repetición y de la diferencia y por otra su recíproca implicación, y que repetición no significa identidad (como también lo sostiene Lotman): «La tache de la vie est de faire coexister toutes les répétitions dans un espace où se distribue la différence» (Différence, 2). Además, ese fenómeno está ligado al problema del origen y del Urbild o Urimagen, que Kahlo supera a través de la repetición, como hace Borges en «Pierre Menard, autor del Quijote». A pesar de poder representar la repetición como una similitud extrema o una equivalencia perfecta, ello no evita marcar una diferencia entre los objetos representados (Différence, 8).

También central para nuestra interpretación de las estrategias mediales de Kahlo es esa ambivalencia entre lo universal y lo particular y su capacidad transgresora a favor de una verdad artística: «Si la répétition existe, elle exprime à la fois une singularité contre le général, une universalité contre le particulier, un remarquable contre l'ordinaire, une instantanéité contre la variation, une éternité contre la permanence. A tous égards, la répétition, c'est la transgression. Elle met en question la loi, elle en dénonce le caractère nominal ou général, au profit d'une réalité plus profonde et plus artiste» (Différence, 9). 
Volviendo a Kahlo, analizaremos el objeto "cámara/cama», que parte de la foto con el torso de yeso de Kahlo que absolutiza lo objetal y lo mitifica, a la vez que la luz y el ambiente lo sacralizan. Tenemos una especie de grial:

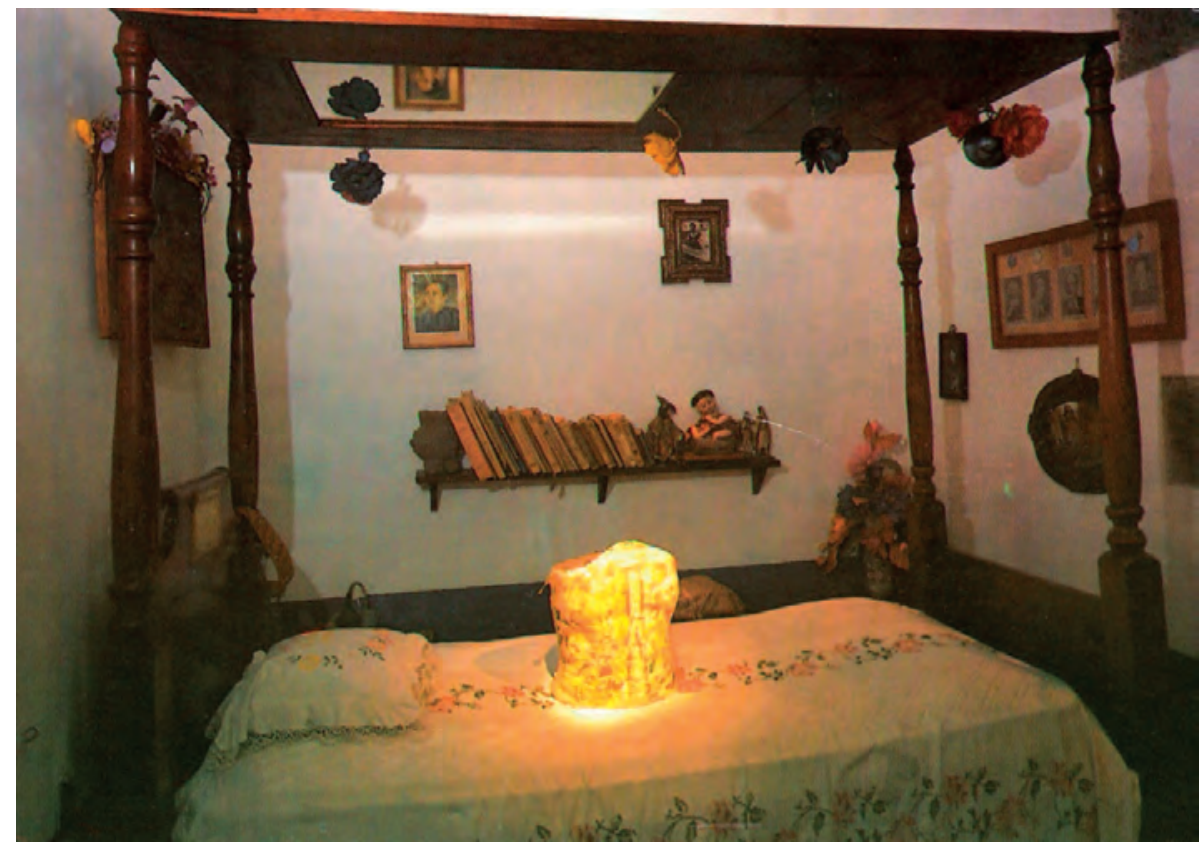

Imagen 6

(Casa azul, recámara y corset de yeso de Frida Kahlo en Coyoacán, México) (c) Museo Dolores Olmedo Patiño

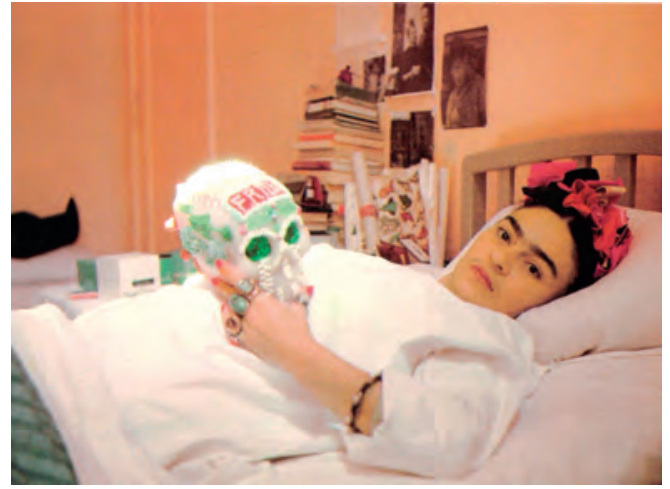

Imagen 7

(Hospitalizada con calavera de azúcar, 1950)

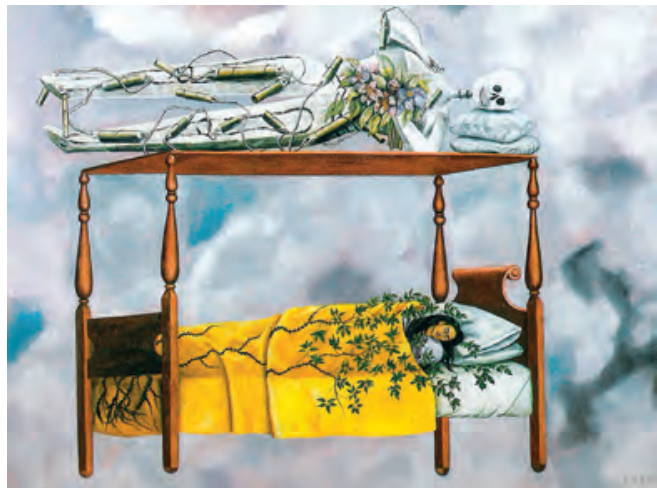

Imagen 8

(de F.K., El sueño (la cama), 1940)

(c) VG Bild-Kunst, Bonn 2011 
El torso de yeso, en este acto casi ritual, es luego reemplazado por Kahlo misma, pero se completa con la calavera que señala la muerte, y que lleva el nombre de Kahlo grabado en la frente (imagen 7). Es una calavera escenificada y pintada, lo que le quita ese poder destructivo y la transforma en un objeto más de la escenografía que se suma al torso iluminado. Aquí se confunden la estrategia de escenificación con la tradición popular, en cuanto la calavera que aparece en la foto es la típica calavera de azúcar que se les regala a amigos y seres queridos el Día de Muertos en México y se hace siempre poniéndole el nombre del que la recibirá como regalo. Como es de dulce, se puede comer ${ }^{1}$.

La calavera podría naturalmente interpretarse como un signo proléptico de su propia muerte, lo cual es subrayado, y podría ser confirmado con la imagen 8 , donde se ubica un esqueleto envuelto en flores y raíces sobre el baldaquín y sobre el lecho vemos a Kahlo también envuelta en ramas y raíces. Sin querer desemantizar esas imágenes, prefiero poner el acento en la capacidad performativa del significante que conlleva la repetición y que nos muestra cómo Kahlo elige cada momento, cada circunstancia y cada toma como objetos artísticos.

En la imagen 9, Kahlo deconstruye la muerte y el esqueleto es un mero objeto decorativo sobre el baldaquín, y así debemos relativizar la interpretación dada antes. Además, Kahlo está plena de vida en ese laboratorio que es su lecho:

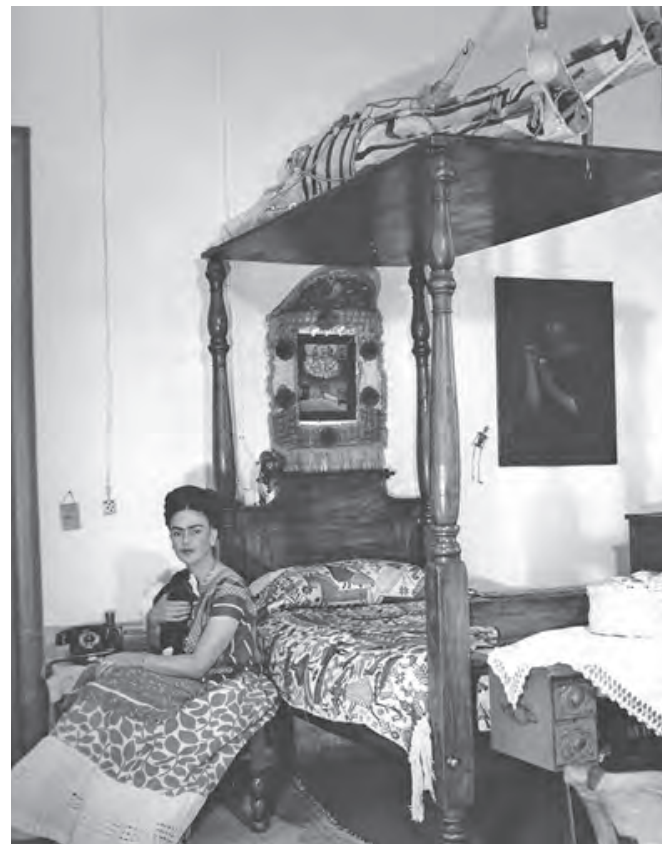

Imagen 9

(B. Silberstein. Frida en su recámara sujetando a un cabrito 1940) @Turner/Océano

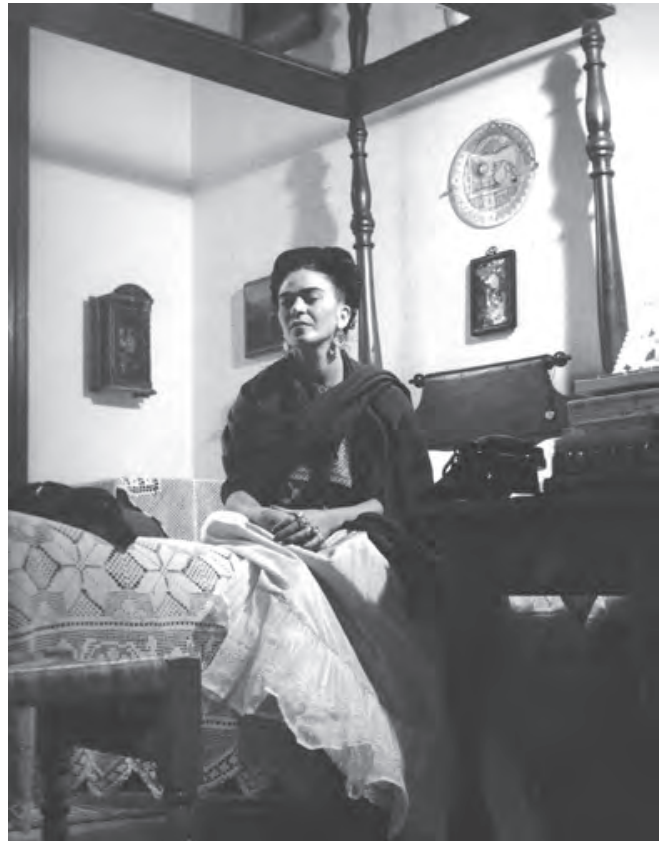

Imagen 10

(L. Álvarez Bravo. Retrato de Frida en la recámara, ca. 1945) @Turner/Océano

Agradezco al Dr. René Ceballos por esta indicación. 
Las dos imágenes, 9 y 10, representan la dinámica de la vida que es coartada y reducida por la silla de ruedas (ver imagen 11). El lecho se transforma en un verdadero altar de combinatoria, el taller de pintura, un objeto más en las construcciones mediales de Kahlo:

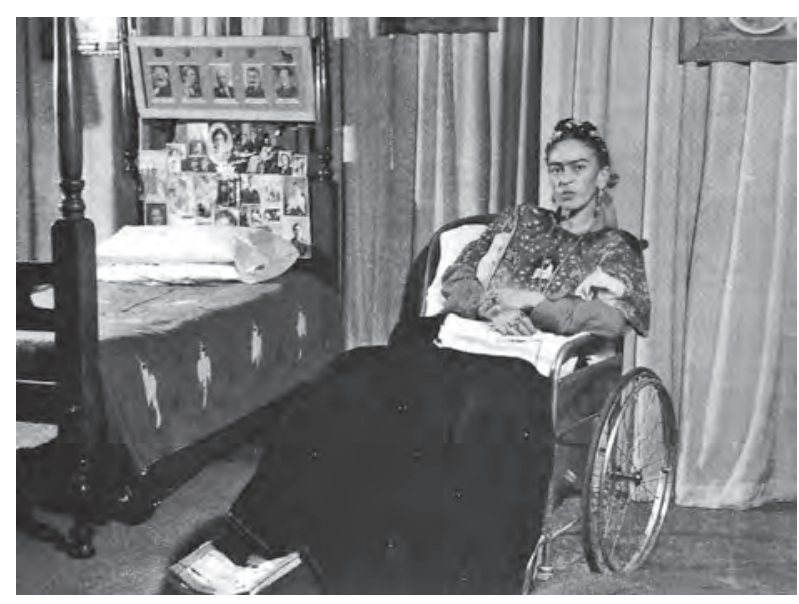

Imagen 11

(Frida después de la amputación de su pierna, 1953) @ L. Alvarez Bravo/S. Greimberg: Hyden Herra, Ed. Diana.
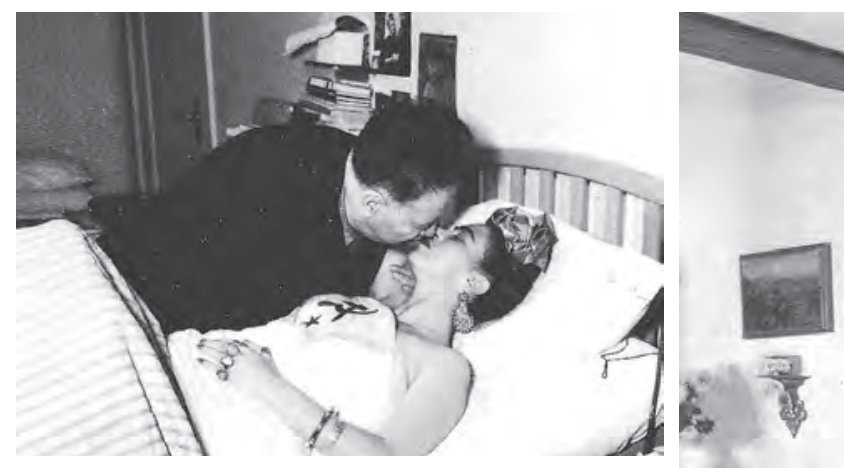

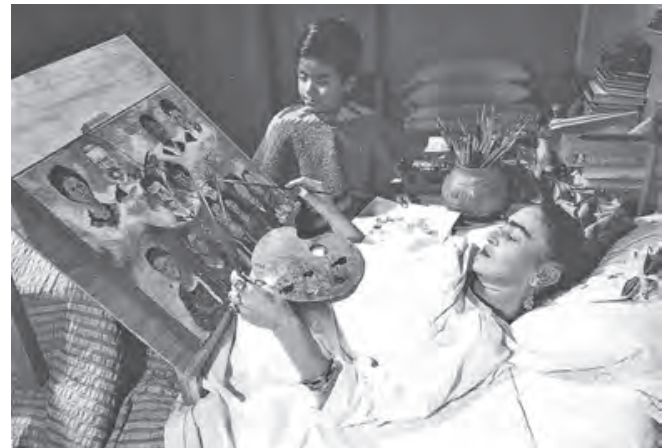

Imagen 12

(Frida con Diego en el hospital inglés, 1951)

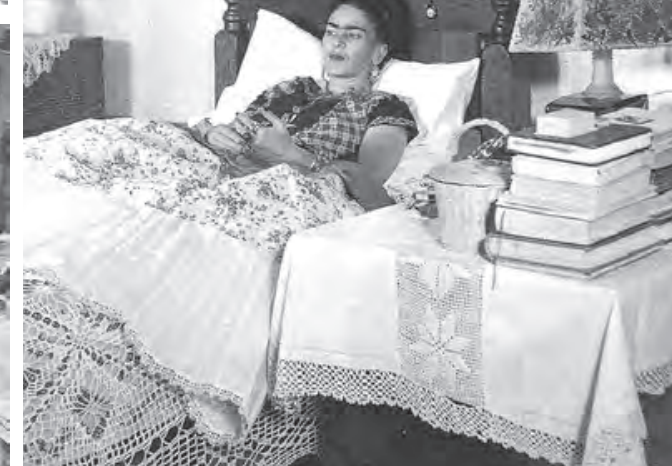

Imagen 13

(Frida en su cama con un espejo en el techo) 


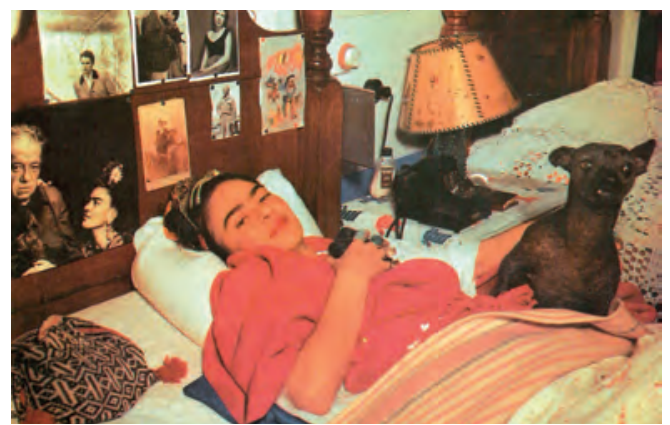

Imagen 14

(En su cama con su perro Señor Xólotl, 1953

Martha Zamora, Centro Comercial Interlomas. México)

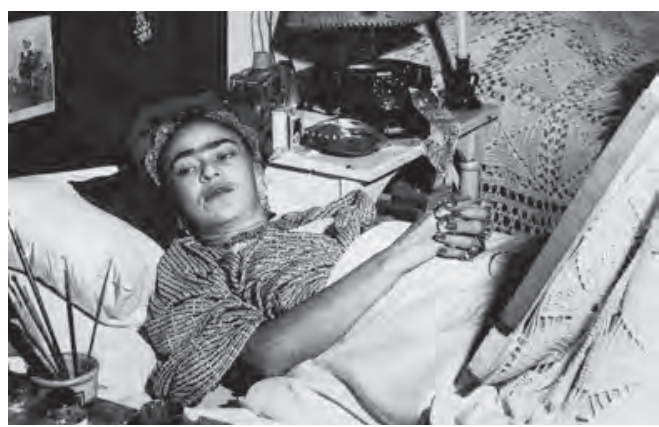

Imagen 15

(de Antonio Rodríguez,

En su cama Marta Zamora, México)

Las fotos de la 9 a la 15 retoman el motivo de la postración, pero en un contexto cotidiano, desritualizan, desmitifican y desacralizan los actos anteriores, produciendo así fluidez y movimiento en la interpretación. Particularmente significativa es la fotografía 15 , donde Kahlo tiene un jarro con sus pinceles, que se puede interpretar como un gesto metapictórico que acentúa la performance, a la cual volveremos más adelante.

La última escenificación y performance es la foto que registra e inmortaliza su último estado, el de la muerte, y así se cierra la serie de los juegos con los elementos de vida y muerte, acción y estatismo, dinámica y esperanza, desvalimiento y desaliento. Kahlo está vestida con los elementos que han ido siendo variados en su vida: los múltiples anillos, el collar, los grandes aros, su cabello recogido en un moño sobre la cabeza, la cinta, etc.

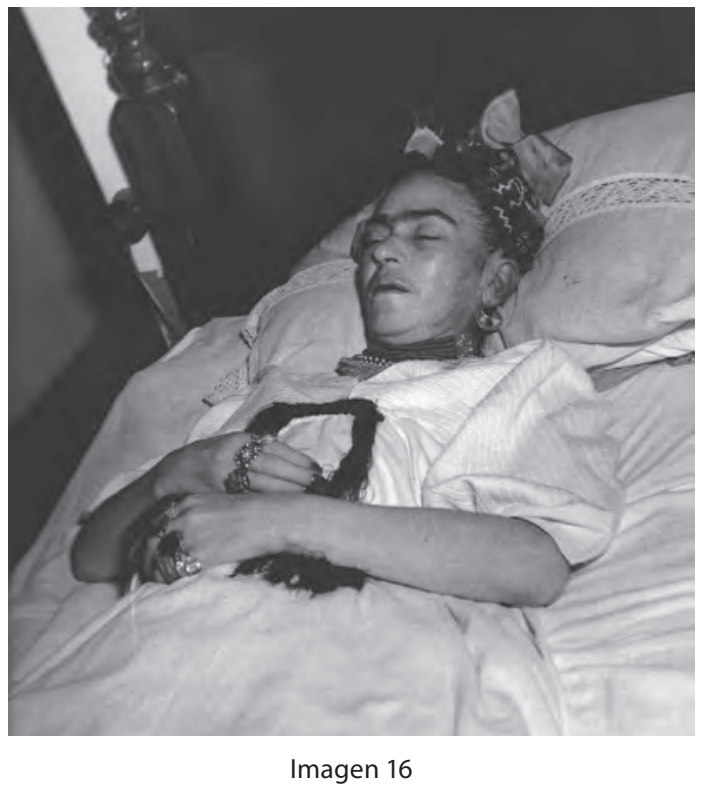

(L. Álvarez Bravo. F.K. en el lecho de su muerte, México 1954) @Turner/Océano 


\section{FOTOGRAFÍA - SERIALIDAD - ALEATORIEDAD}

Roland Barthes, en una línea similar a la de Deleuze, considera que «[c]e que la Photographie reproduit à l'infini n'a eu lieu qu'une fois: elle répète mécaniquement ce qui ne pourra jamais plus se répéter existentiellement. En elle l'événement ne se dépasse jamais vers autre chose: elle ramène toujours le corpus dont j'ai besoin au corps que je vois; elle est le Particulier absolu» (La chambre, 15).

La fotografía no es algo estático para Barthes, ya que está configurada por un operateur, el fotógrafo, y por el spectator, el receptor o espectador y la referencia, el objeto que denomina el spectrum de la fotografía, que es el simulacro o eidôlon emitido por el objeto (La chambre, 22). Esa situación comunicativa tiene consecuencias determinantes para la construcción del objeto fotografiado, en cuanto representa una disociación que se refleja en la constitución de la comunicación óptica y en la conciencia del sujeto fotografiado, que es transformado en un objeto a través de la escenificación y performance. La creación del «appuie-tête», que menciona Barthes (La chambre, 29), contribuyó en su época a la transformación del sujeto en objeto en su función proteica. La persona fotografiada, en particular en el género del foto-retrato, es aquella «que je me crois, celui que je voudrais qu'on me croie, celui que le photographe me croit, et celui dont il se sert pour exhiber son art» (29). Esa situación particular que Barthes denomina «action bizarre» (29) es lo que denominamos escenificación y performación, y ese acto se desarrolla queriendo o no escenificarse. Ya el acto de ponerse frente a una cámara es un acto de escenificación y de performancia. Kahlo, en la gran cantidad de fotos que se hizo tomar, pasa a ser sujeto y objeto de la imitación, es su propio actor, es un acto de autorrepresentación que cada vez marca esa «action bizarre», es decir, su artificialidad y particularidad. Kahlo como objeto o como sujeto autoimitante produce un desprendimiento de sí misma (Entäußerung), que luego se fragmenta a través de la repetición serial y aleatórica. Así, la imagen 17 no es Frida Kahlo, y menos aún lo es la imagen 18.

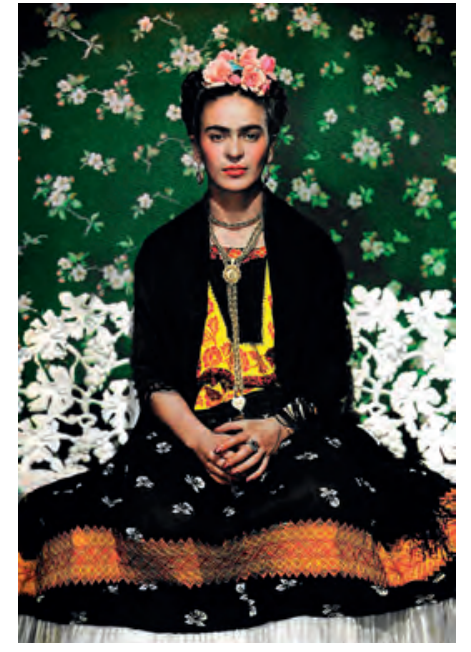

Imagen 17

(Frida en banca blanca, New York 1939, Schimer/Mosel, München) ๑ Nickolas Muray

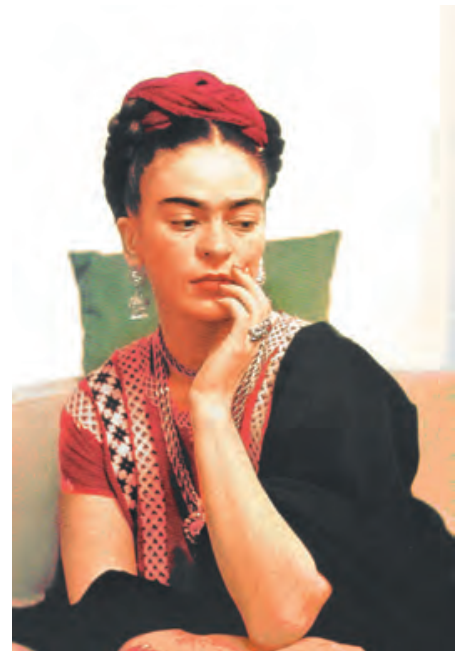

Imagen 18

(Frida, New York 1938. Schimer/Mosel, München) (c) Nickolas Muray, 
En ellas, por una parte, quiere representarse como se siente y se ve ella misma y como la ve el fotógrafo, y por otra parte es configurada con una identidad que la foto construye: «la pose». La pose es la performance misma del cuerpo en acción y aquello que Barthes formula como: «je ne suis ni un sujet ni un objet, mais plutôt un sujet qui se sent devenir objet [...] je deviens vraiment spectre» (La chambre, 30), y es lo que lleva al espectador al deseo, a la avidez de captar el punctum de acciones infinitas a donde nunca se llega: Kahlo es indeterminable.

La pose transforma al fotografiado en personaje-objeto, en un actor, un performer que tiene una similitud con los seres de carne y hueso. El personaje observado es animado con la mirada y la foto comienza a narrar y así se transforma en una aventura. El Blickpunkt, o como Barthes dice, el «punctum», el análisis y el estudio que nos revela lo sustancial, lo esencial de una foto: "[...] punctum, c'est aussi: piqûre, petit trou, petite tache, petite coupure - et aussi coup de dés. Le punctum d'une Photo, c'est ce hasard qui, en elle, me point»(La chambre, 49; el destacado es mío). La pose es ese lugar ambiguo que transversaliza (cruza) la realidad y la ficción, lo estático y lo dinámico, la vida y la muerte.

Hablábamos de lo accional, de lo performativo de la fotografía y de la pose, que es el momento en que se entra en la performancia y con ello la foto de la persona representada no es una reproducción de una biografía, ya que la persona pasa por la mímesis, primero de sí misma, luego del paso del referente al medio de contacto (la máquina fotográfica, el negativo o el microchip y el papel o la escritura), por lo que nos parece más adecuado, siguiendo a Barthes, hablar de «biografemas", o como quisiera reformularlo de "biofotofemas", que sostienen con la biografía la misma relación que sostiene la fotografía con la historia (La chambre, 54). Por ello, no consideramos el término performance en sus terminología y en parte en su práctica sui generis, sino como en el fluxus relacionado con la fotografía y la fotografía estrechamente entrelazada con la pintura. Nuestro punto de partida es exactamente ése: consideramos que tanto la fotografía como la pintura de Kahlo están estrecha y simbióticamente relacionadas y ambos sistemas mediáticos son formas de expresión performativas. Barthes apunta a esa relación siamesa cuando afirma que «Rien ne distingue, eidétiquement [...] une photographie, si réaliste soit-elle, d'une peinture. Le ‘pictorialisme' n'est qu'une exagération de ce que la Photo pense d'elle-même» (La chambre, 55).

Otro aspecto importante es que también Barthes se refiere al teatro en relación con la fotografía en cuanto a arte: "Ce n'est pourtant pas [...] par la Peinture que la Photographie touche à l'art, c'est par le Théâtre» (La chambre, 55), y más aún, en nuestra línea de investigación, Barthes relaciona la fotografía dentro de su contexto comunicativo entre operateur y spectator con la performance: «mais pour le Photographe, ce sont autant de 〈performances»» (57). Pero no solamente el fotógrafo es el performador, sino mucho más la persona fotografiada.

La fotografía es una lata de conserva de la vida, que por ello además marca una cesura entre vida y muerte, es el lugar de la ilusión más perfecta y de la ausencia de lo real: «Telles sont les deux voies de la Photographie. A moi de choisir, de soumettre son spectacle au code civilisé des illusions parfaites, ou d'affronter en elle le réveil de l'intraitable réalité» (Barthes, La chambre, 183-184). 
Kahlo repite las poses una y otra vez, la fotografía repite el motivo Kahlo y Kahlo repite el motivo en la pintura. Lo dicho para la fotografía vale igualmente para la pintura: tenemos un juego permanente entre diferencia y repetición.

A continuación analizaremos algunas series de imágenes en una secuencia que no parte primeramente de la cronología en que, por ejemplo, fueron tomadas las fotos o los retratos pintados, sino de la perspectiva del espectador y del que está describiendo las fotos, pero también del acto de performancia de Kahlo. Mi descripción es conducida por el punctum de Barthes, que se encuentra estrechamente relacionado con la Logique de la sensation de Deleuze (1984) y por la complejidad del objeto analizado. Siguiendo a Deleuze, podemos afirmar que tanto a la fotografía como a la pintura en su forma sintética y absolutamente sincrónica les es imposible reproducir un modelo o contar una historia, y de allí que existan dos posibilidades para librarse de lo figurativo: producir una forma pura a través de la abstracción (que no es el caso de Kahlo) o producir una figuración pura a través de la extracción o del aislamiento (Logique, 9). Hemos elegido cuatro series de imágenes: «serie 1: rostros, peinado partido en medio y medio cuerpo", "serie 2: retrato con monos y loros", «serie 3: cigarrillo»y «serie 4: Frida y Diego».

\section{SERIE 1: ROSTROS, PEINADO DE RAYA EN MEDIO Y MEDIO CUERPO}

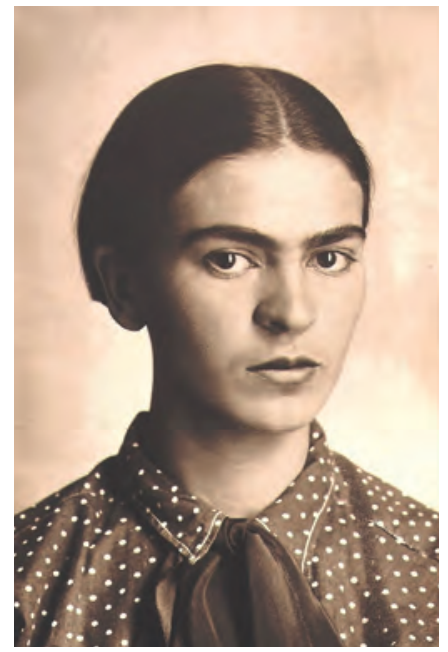

Imagen 1

(de G. Kahlo 1926, México)

(c) Turner/Océano

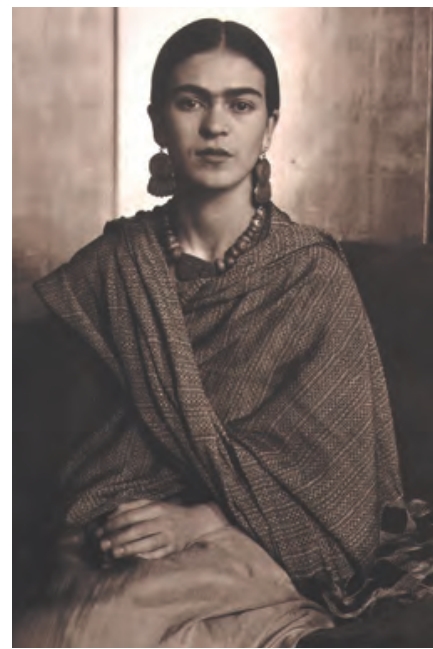

Imagen 2

(de Imagen Cunningham 1939, San Francisco) @Turner/Océano

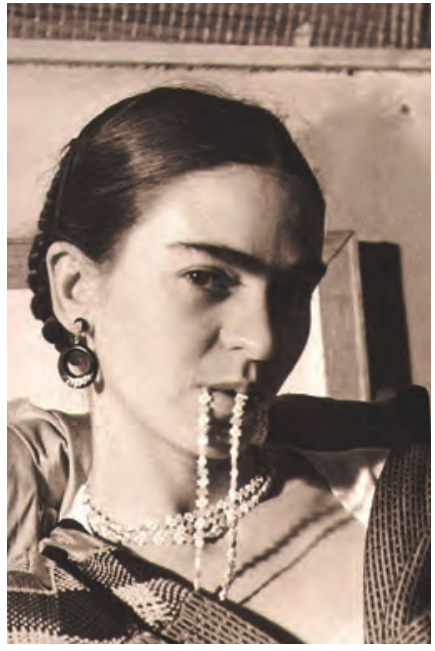

Imagen 3

(de Lucienne Bloch. Frida mordiendo su collar. Nueva York 1933) @Turner/Océano 


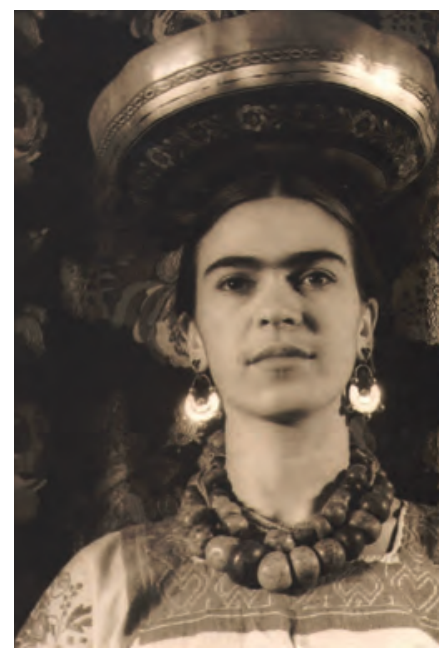

Imagen 4

(de Carl van Vechten Nueva York 1932. Frida con una jícara de Tehuantepec en la cabeza) oTurner/Océano

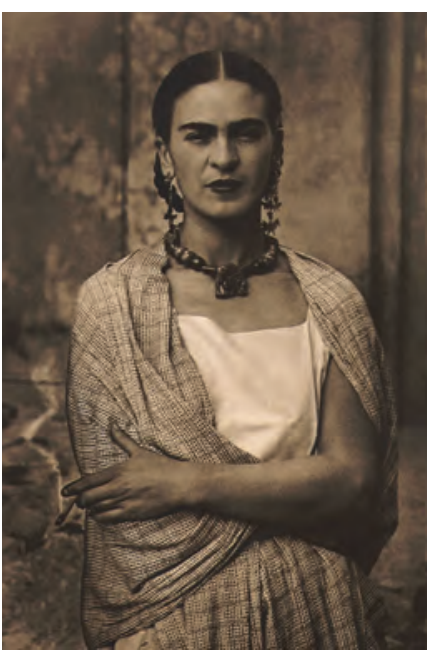

Imagen 7

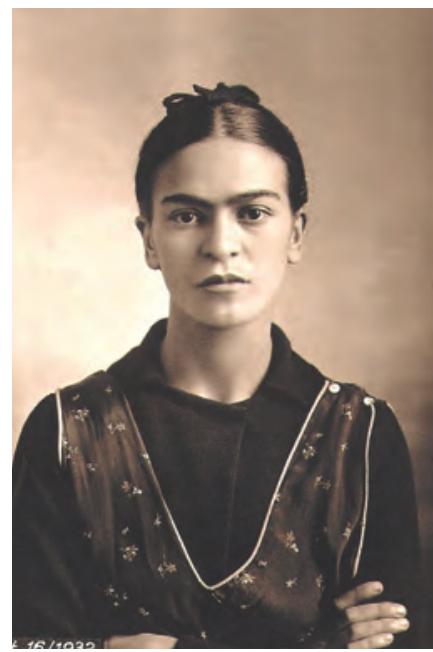

Imagen 5

(de G. Kahlo 1932, México) oTurner/Océano

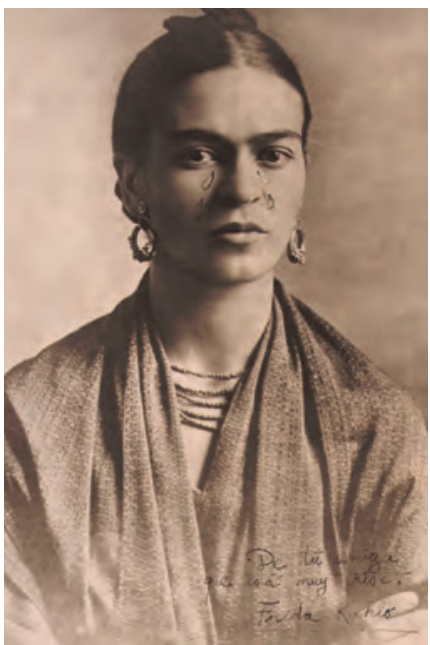

Imagen 6

(de G- Kahlo 1932, México.Tu amiga que está muy triste, F.K.)

(c) Turner/Océano

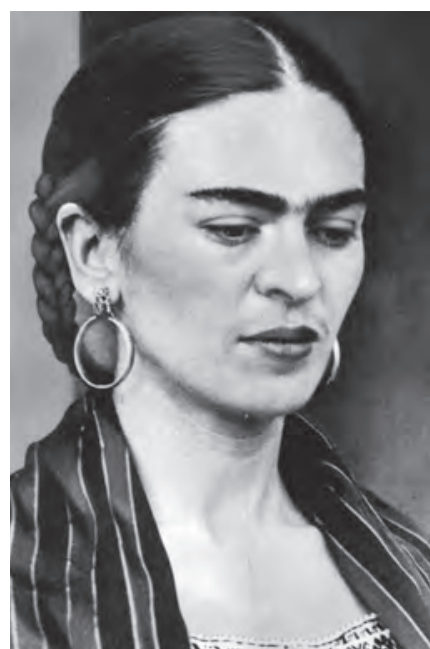

Imagen 8

(de Fritz Henle, Frida con rebozo a

rayas, 1936)

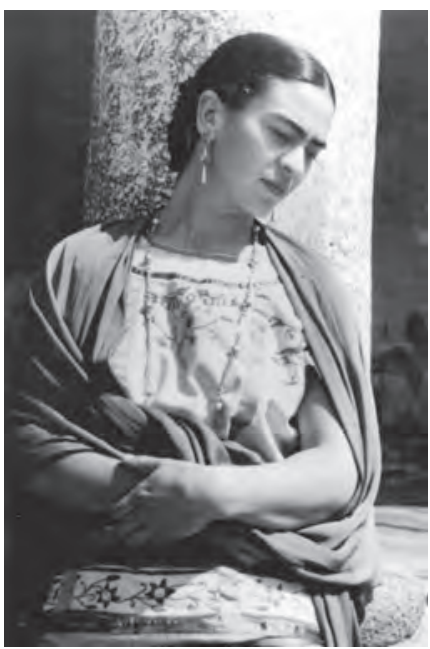

Imagen 9

(de Fritz Henle, Frida con blusa bordada) 


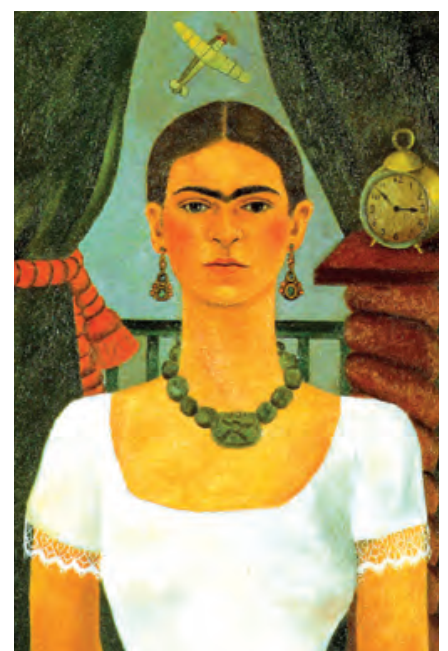

Imagen 10

(de F.K. El tiempo vuela 1929)

(c) VG Bild-Kunst, Bonn 2011

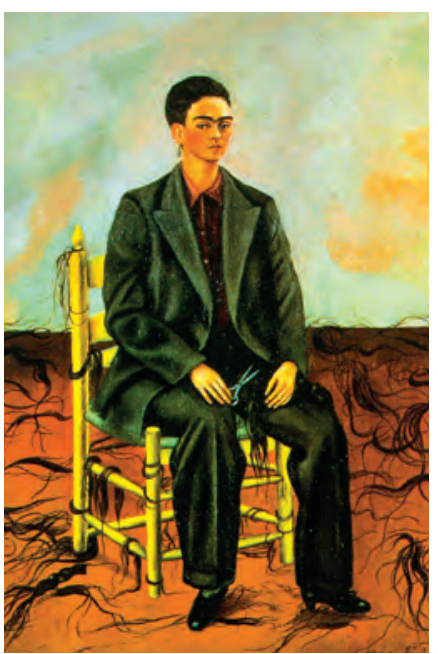

Imagen 13

(de F.K.: Autorretrato con pelo corto 1940)

(c) VG Bild-Kunst, Bonn 2011

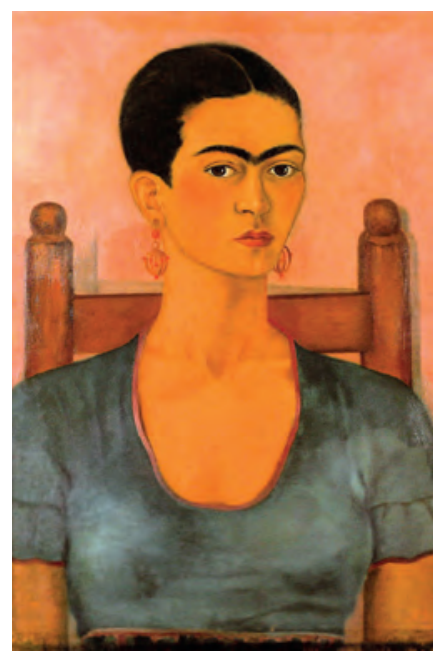

Imagen 11

(de F.K. Autorretrato 1930)

(c) VG Bild-Kunst, Bonn 2011

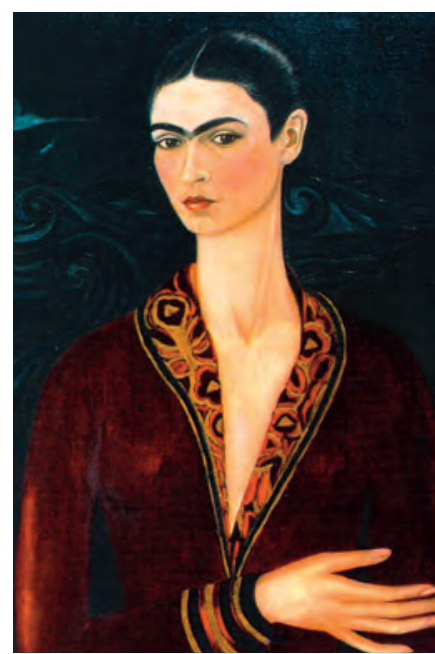

Imagen 14

(de F.K.: Autorretrato con traje de terciopelo 1929) ๑ VG Bild-Kunst,

Bonn 2011

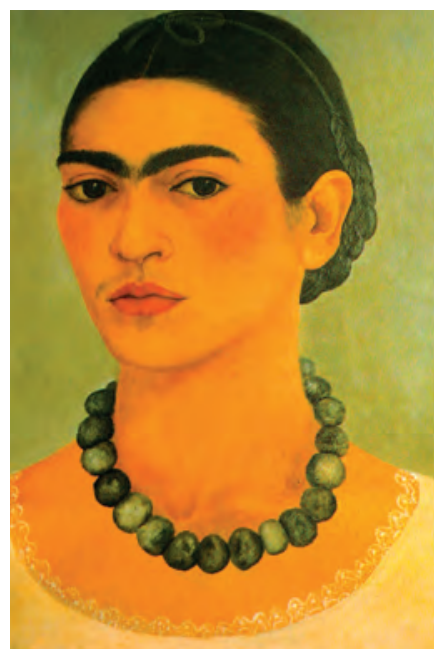

Imagen 12

(de F.K. Autorretrato con collar 1933)

(c) VG Bild-Kunst, Bonn 2011

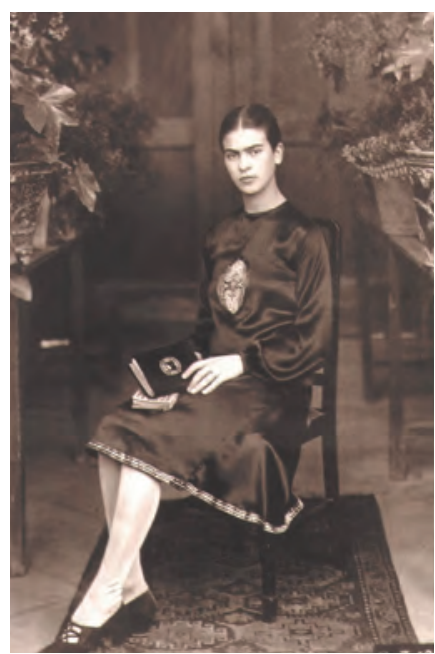

Imagen 15

(de G. Kahlo 1926,

México)

OTurner/Océano) 


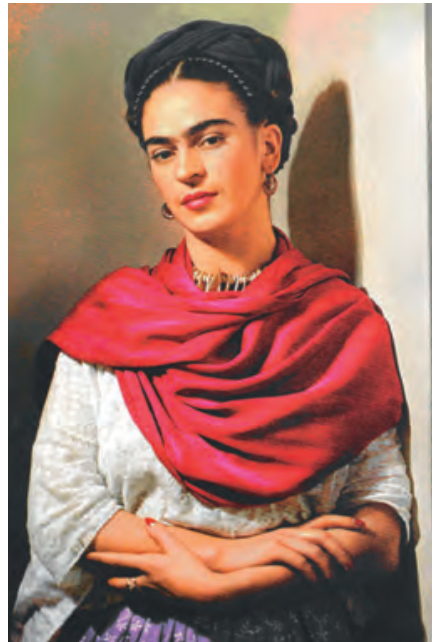

Imagen 16

(de N. Muray. rebozo lila, Nueva York 1939) @Turner/ Océano

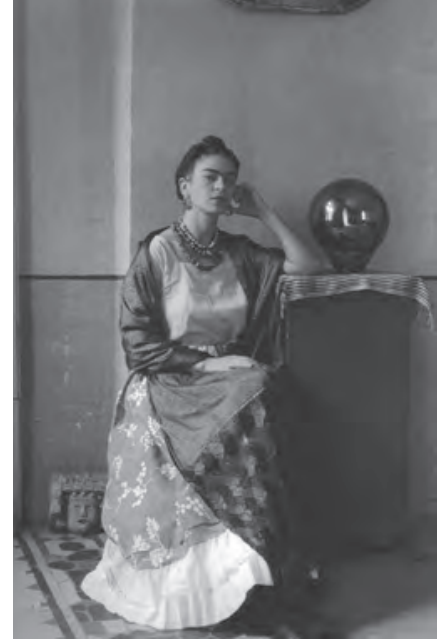

Imagen 17

(de M. Álvarez Bravo. Frida con esfera, Coyoacán 1938) @Turner/Océano

\section{SERIE 2: RETRATO CON MONOS Y LOROS}

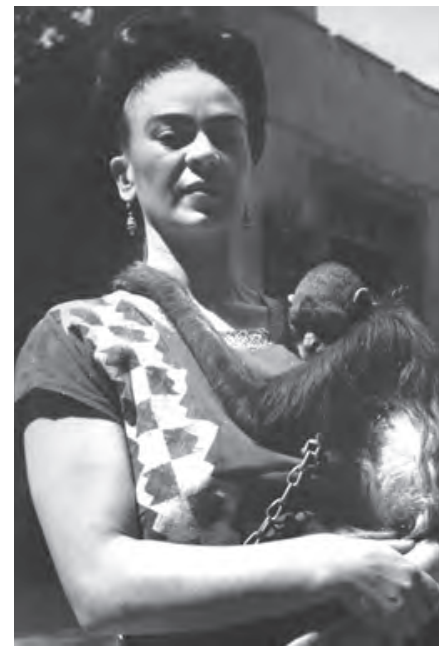

Imagen 1

(de F.K.: Autorretrato con mono 1938) @ VG Bild-Kunst, Bonn 2011

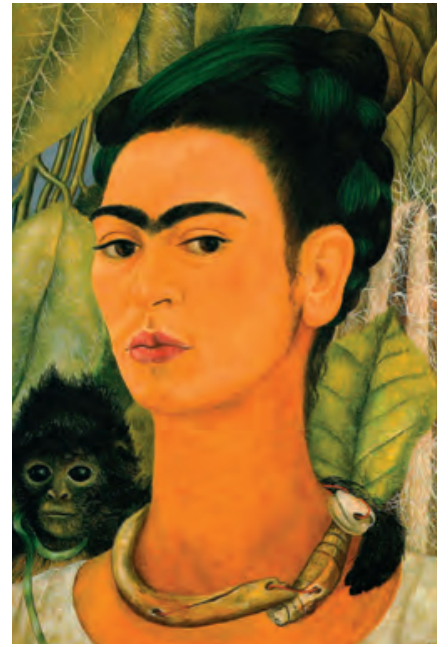

Imagen 2

(de F.K.: Autorretrato con mono 1940) ๑ VG Bild-Kunst, Bonn 2011

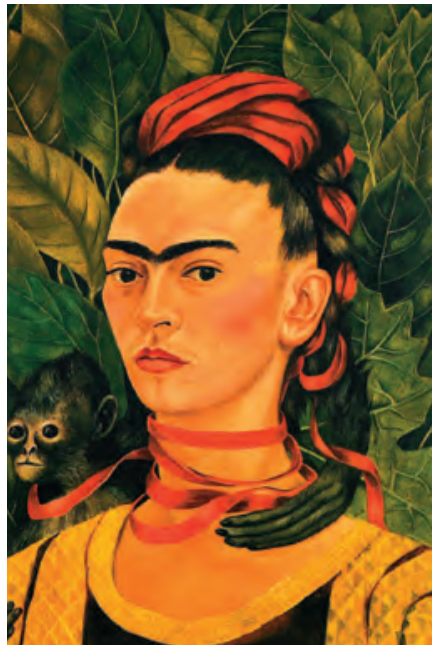

Imagen 3

(de F.K.: Fulang Chang y yo 1937)

(c) VG Bild-Kunst, Bonn 2011 


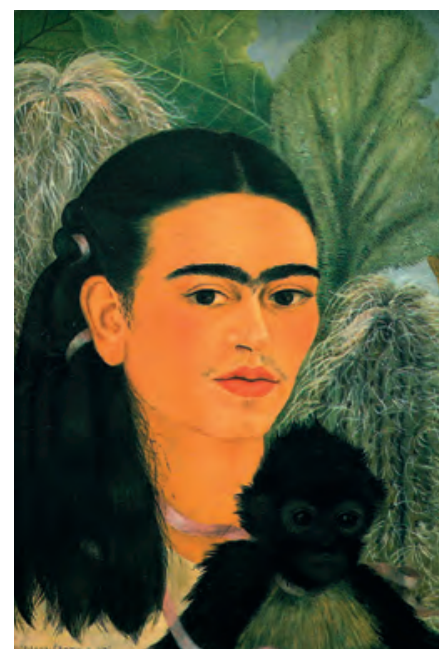

Imagen 4

(de F.K.: Autorretrato con Bonito 1941) @ VG Bild-Kunst, Bonn 2011

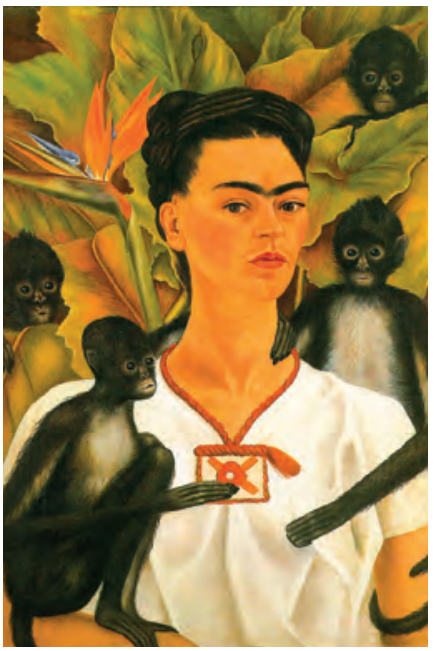

Imagen 7

(de F.K.: Autorretrato con monos 1943)

(c) VG Bild-Kunst, Bonn 2011

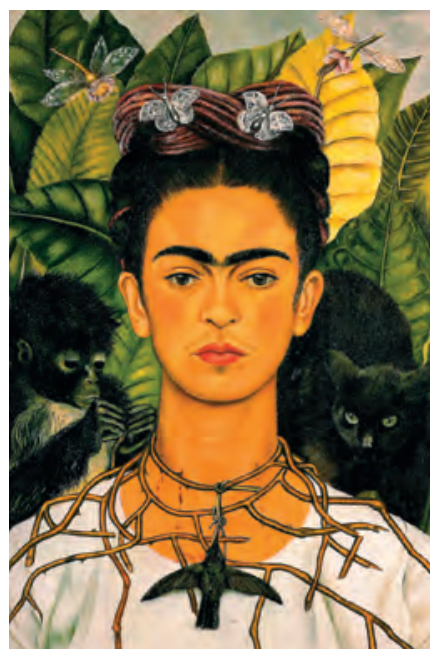

Imagen 5

(de F.K.: Autorretrato con Collar de Espinas y Colibri 1940) ๑ VG BildKunst, Bonn 2011

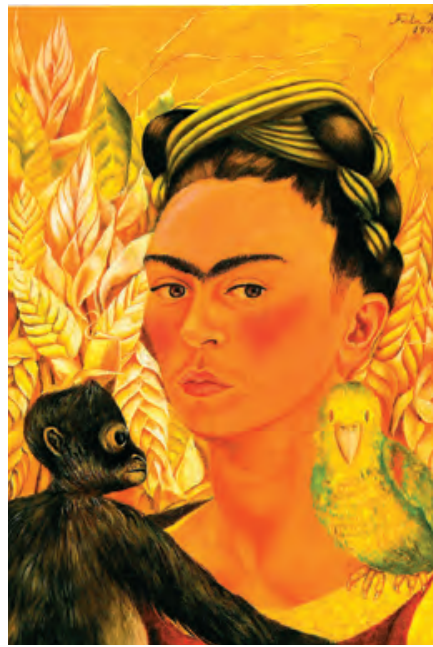

Imagen 8

(de F.K.: Autorretrato con mono y loro 1942)

(c) VG Bild-Kunst, Bonn 2011

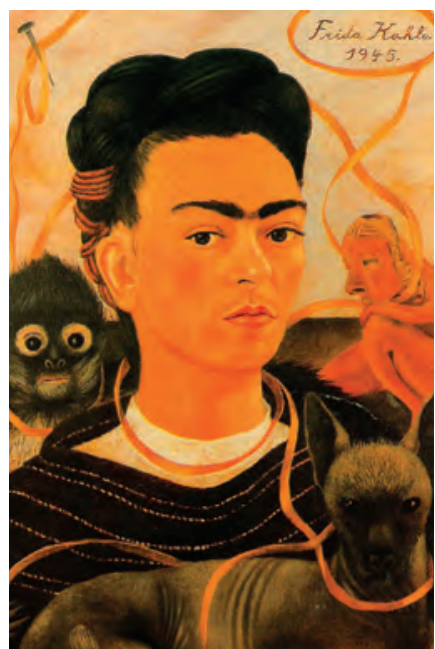

Imagen 6

(de F.K.: Autorretrato con changuito 1945) @ VG Bild-Kunst, Bonn 2011

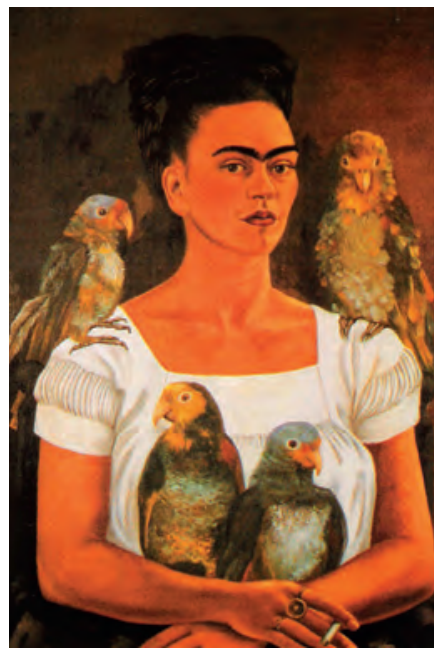

Imagen 9

(de F.K.: Yo y mis loros 1941)

c) VG Bild-Kunst, Bonn 2011 


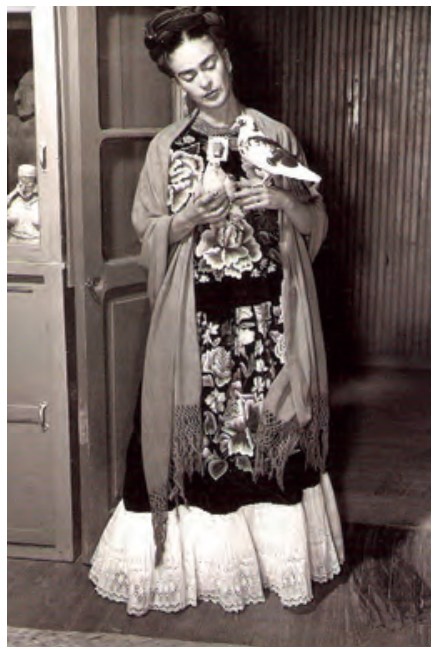

Imagen 10

(Fritz Henle, Frida con mono frente a su estudio, de

J. Guzmán. Frida Kahlo con dos pájaros, ca. 1950) OTurner/Océano

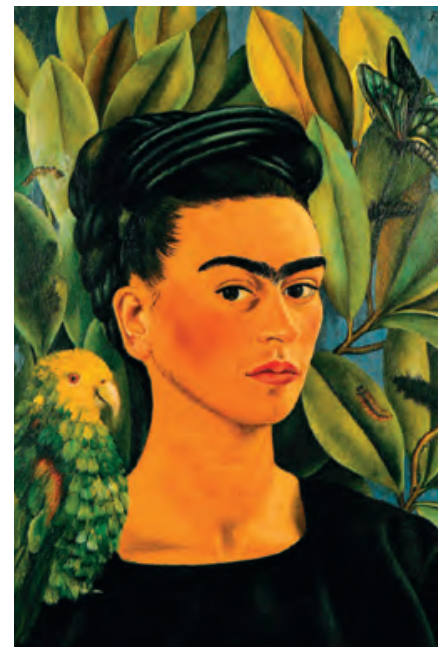

Imagen 11

(de F.K.: Yo y mis loros 1941)

(c) VG Bild-Kunst, Bonn 2011

\section{SERIE 3: CIGARRILLO}

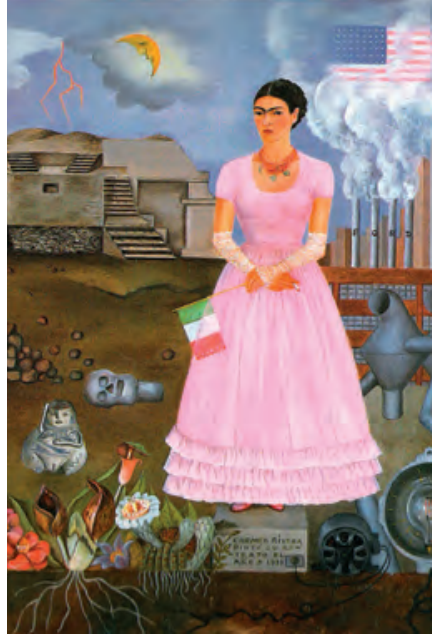

Imagen 1

(En la frontera entre México y EE.UU. 1932) @ VG BildKunst, Bonn 2011

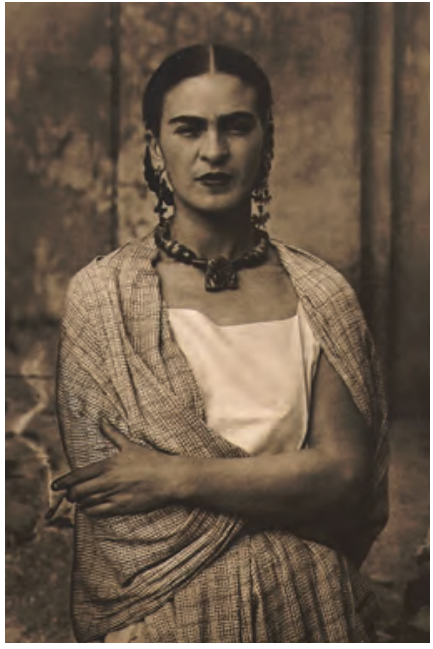

Imagen 2

(de G. Kahlo, México 1932)

(c) Turner/Océano) 


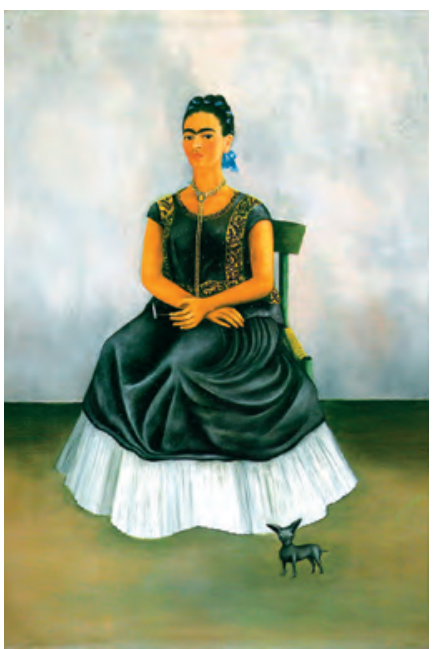

Imagen 3

(de F.K.: Un perro de raza itzcuintli y yo 1938) (c) VG Bild-Kunst, Bonn 2011

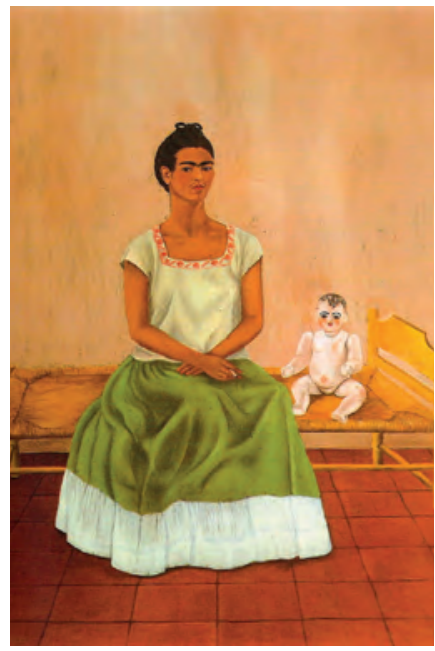

Imagen 5

(de F.K.: Yo y mi muñeca 1937) ๑ VG Bild-Kunst, Bonn 2011

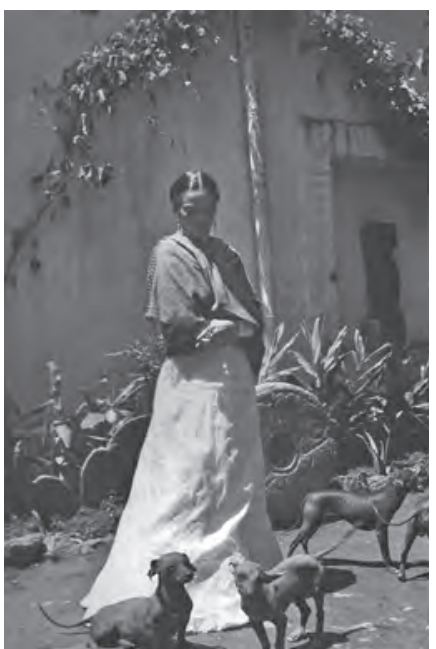

Imagen 4

(G.Freund, En el jardín de la Casa Azul de Coyocán 1951)

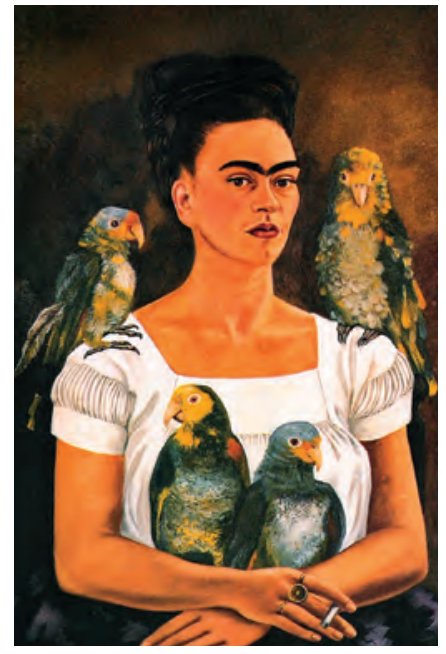

Imagen 6

(de F.K.: Yo y mis loros 1941) @ VG Bild-Kunst, Bonn 2011 


\section{SERIE 4: FRIDA Y DIEGO}

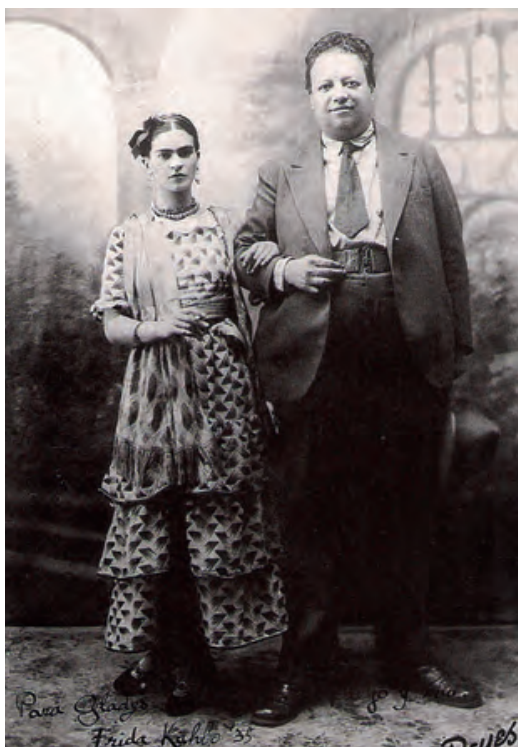

Imagen 1

(Foto oficial de la D.R. 1931 CatExpMex)

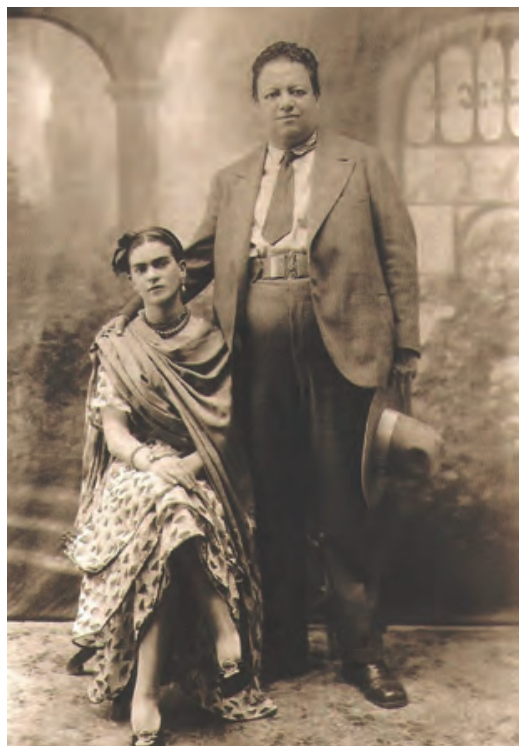

Imagen 3

(de V. Reyes 1929 San Ángel, 1941), OTurner/Océano

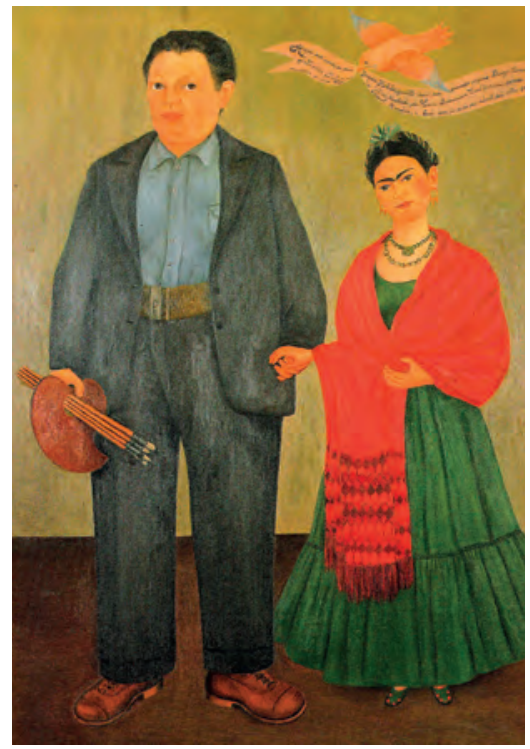

Imagen 2

(de F-K. Con mi amado esposo Coyoacán) @Turner/ Océano, ( ) VG Bild-Kunst, Bonn 2011

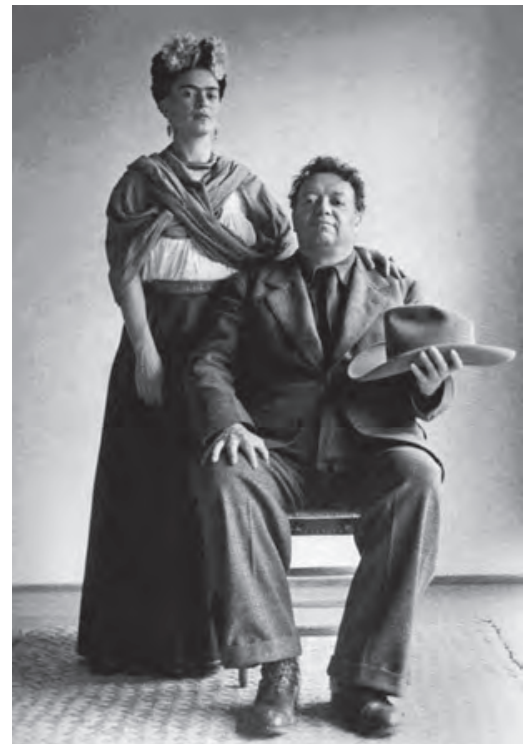

Imagen 4

(de N. Muray. Frida y Diego, boda 1929) 
Tenemos una serie de retratos-fotografías y pinturas con una buena cantidad de variaciones de elementos y colores. Particular es la impasibilidad o una especie de rigidez en el rostro de Kahlo, tanto en las fotografías como en sus autorretratos, que es una marca para toda su producción. La repetición del motivo general es idéntica, «Frida Kahlo» acompañada de otros elementos (de animales, flores o de Diego). Las fotografías se organizan en series, serialidad que se potencia en directa relación con los cuadros que vuelven a repetir el motivo y que marca la diferencia. Kablo hace fotografía con la pintura y hace pintura con la fotografía como performance, repite y varía. Las diversas poses que ponen en movimiento el retrato y enfatizan las similitudes y diferencias nos llevan a la pregunta: ¿cuál es el punctum de estas fotografías que a través de su serialidad se ficcionalizan y nos revelan su constructividad y performatividad? Repetición y diferencia se transforman además en un elemento de metapicturalidad.

La primera imagen de la serie muestra una Frida sorprendida y atrapada en una pose que el fotógrafo ha marcado. En la segunda imagen se nos presenta una Frida desafiante y en la tercera y cuarta se refleja en su rostro el placer de la pose y del exhibicionismo, con diversos matices que produce la calma y que la lleva a actuar donde concurren la perspectiva del fotógrafo y de Frida. A partir de la imagen 5 tenemos un cambio sustancial, que retoma en parte la actitud de la imagen 2, que hace de puente, que se desliza hacia las imágenes posteriores, pero que se le agrega algo de escepticismo y reproche, estado que se sintetiza en la imagen 6 y remata en la imagen 8 y 9, donde se nos presenta una Frida pensativa, introspectiva, que se escapa y escurre a la perspectiva y al poder del fotógrafo. Las imágenes-pinturas retoman los motivos de las fotografías 1, 2, 6 y 7, agregando collares y aros o blusas de diverso color y forma. La imagen 14, «El autorretrato con traje de terciopelo» de 1929, tiene como evidente referencia las imágenes 1 y 15 de 1926, pero que se encuentra también en otras realizaciones en las imágenes 18 a 20, que se contraponen a la estilización clásica de la imagen 14. En todos los retratos-fotografías y pinturas autorretratos se produce una iteración de la posición y de los elementos, una habitualización y desgaste. Pero el punctum radica en la mirada, la posición de los párpados: esto es lo que le da la intensidad y transmite intensidades al espectador, es esa contradicción entre la dinámica de la mirada y lo estático del resto del cuerpo, es esa ambigüedad o contradicción la que produce una tensión y el sentimiento de que el objeto Kahlo se escapa de la posesión o aprehensión del observador, haciendo así circular el deseo, el fetiche, la mitificación como instrumento de compensación.

\section{METAPICTURALIDAD}

Un último tema por tratar es una característica fundamental del trabajo de Frida Kahlo: la «reflexibilidad», «mise en abyme», «especularidad» o «metapicturalidad», tanto en su trabajo activo como personaje y performer, en la fotografía como en sus pinturas. La conciencia de Kahlo de que está escenificando, produciendo un happening y con ello una obra de arte del momento de su instalación es más que evidente, como puede demostrarse en las siguientes imágenes. Se emplean varias técnicas: una es la del espejo o del autoespejo o la técnica «Velázquez», donde se refleja cómo la otra Kahlo desenmascara lo real como un artificio. 


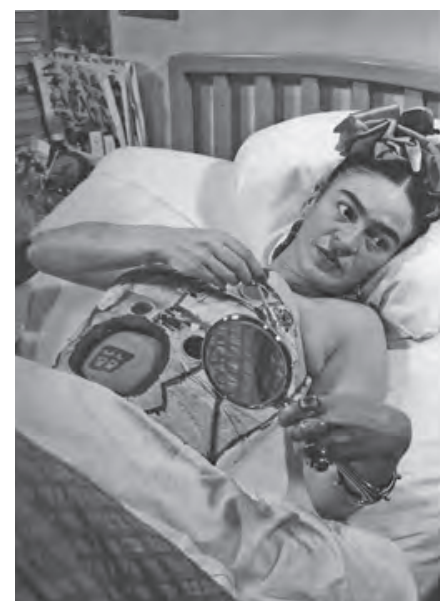

Imagen 1

(J. Guzmán. F.K. en la cama del hospital sujetando un espejo. México, c. 1950) @Turner/Océano

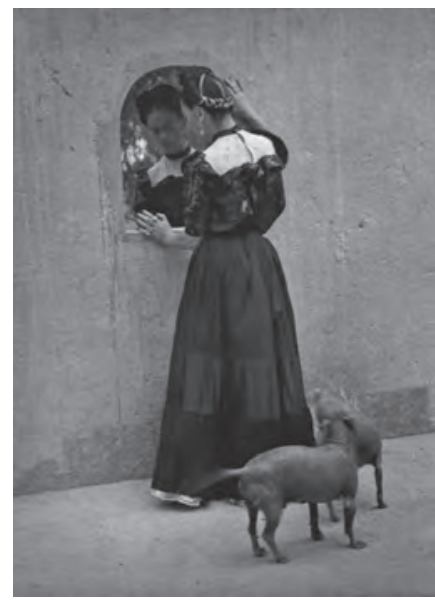

Imagen 2

(de L. Álvarez Bravo. Frida mirándose en un espejo en el patio de la Casa Azul 1942)

oTurner/Océano

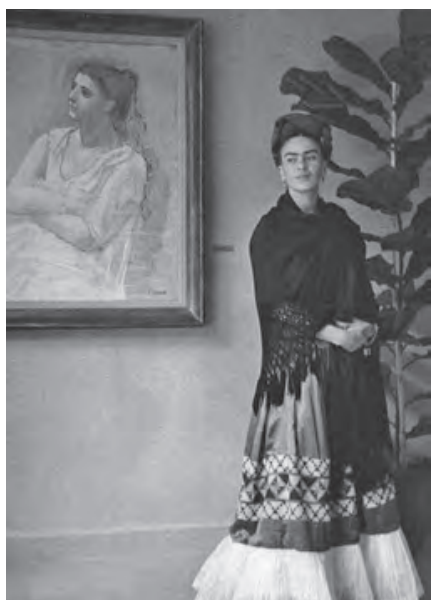

Imagen 3

(de M. Álvarez Bravo. F.K.. en la exposición de Picasso. México 1944) oTurner/Océano

En la imagen 1, Kahlo es el objeto de una fotografía y ella a su vez refleja su rostro y parte de su pecho, duplicando el acto de representación y reflejándolo en contra de la fotografía, como una especie de respuesta de autofotografía. En la imagen 2, Kahlo se refleja en un espejo del patio transformando su cuerpo real en virtual. En la imagen 3, Kahlo se encuentra frente a un retrato de una mujer pintado por Picasso, que la involucra como mujer retratada y la relaciona con el cuadro por reminiscencia en su calidad de mujer, de mujer retratada en fotografías y pinturas en poses similares.

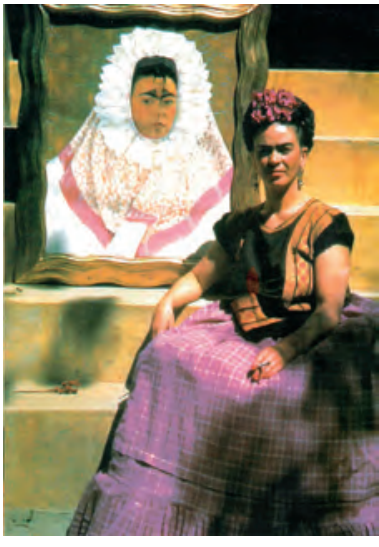

Imagen 4

(Con el autorretrato Diego en mi Pensamiento,1943)

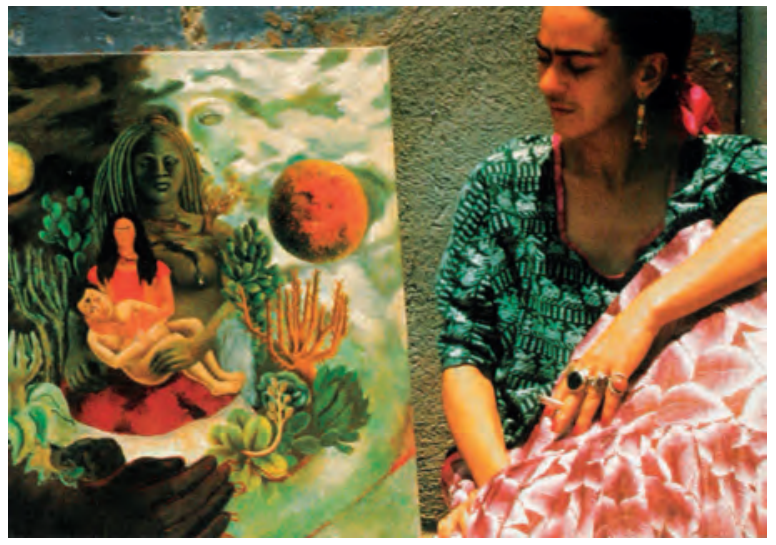

Imagen 5

(Con el autorretrato El Abrazo de Amor de El universo, la Tierra (México), Yo, Diego y el Señor Xólotl, 1949) 
La imagen 4 y 6 subrayan la diferencia entre Kahlo pintora sentada al lado de su cuadro y Kahlo como tehuana. Ése no es un autorretrato, es una escenificación de Kahlo con una capucha de tehuana que además no tiene realmente una conexión directa con ella. Fuera de que la imagen sea además el producto de una fotografía y de que Kahlo como que ha metido su cabeza en esa capucha, como se hace con esas figuras de cartón en las ferias donde los fotógrafos hacen tomas a personas con una vestimenta determinada.

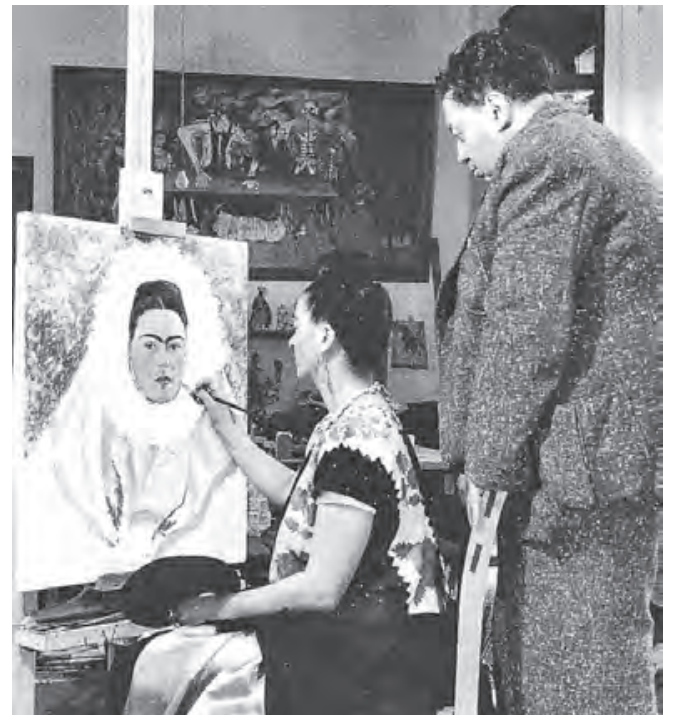

Imagen 6

(de B. Silberstein. Frida pintando su autorretrato mientras Diego observa México, ca. 1940) @Turner/Océano

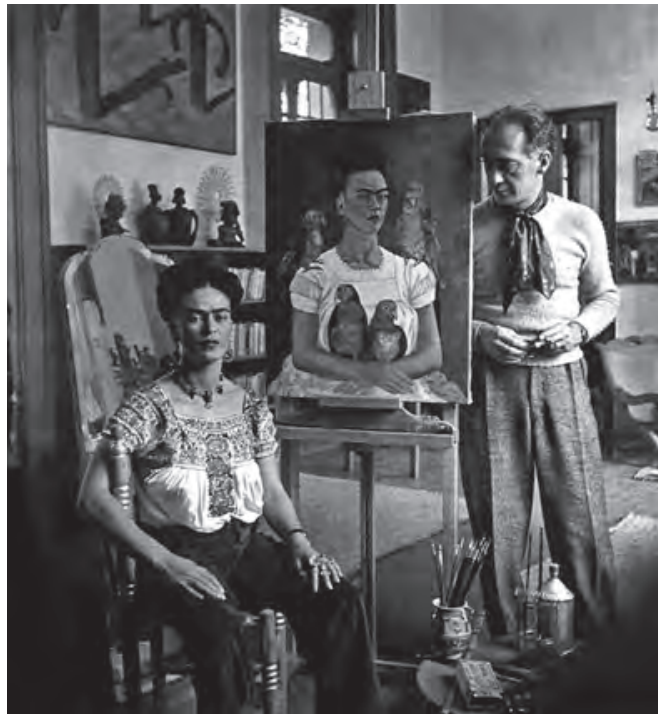

Imagen 7

(de N. Muyar, Frida y Nick en el atelier de Frida en Coyoacán, 1941) @Turner/Océano

En esa construcción se usa el rostro de Kahlo como material pictórico, que además es potenciado, primero, por la fotografía donde está sentada al lado del cuadro, marcando la repetición y las diferencias y, segundo —en cuanto Diego la observa (imagen 6) - cómo ella se transforma en objeto performativo. Finalmente, la foto de Silberstein introduce otro nivel de repetición y diferencia. 


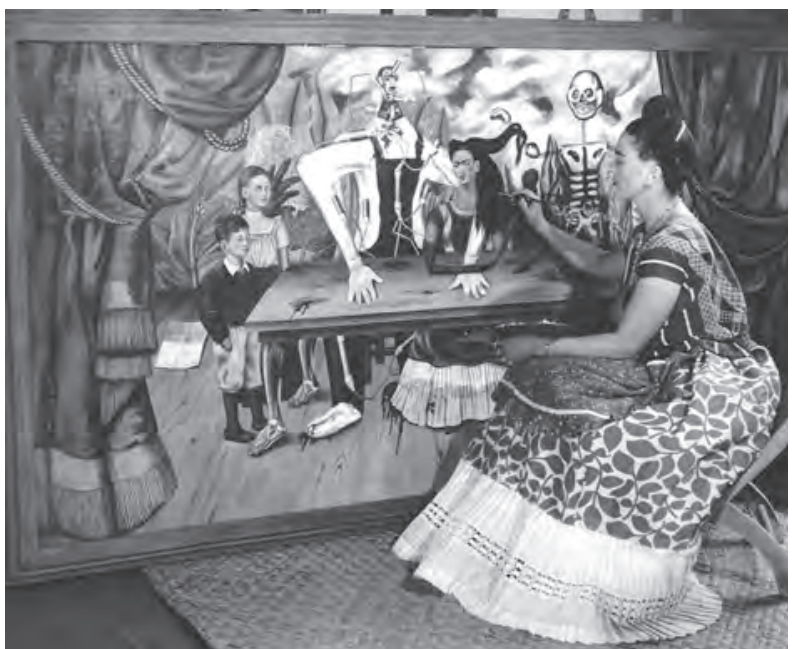

Imagen 8

(de B. Silberstein Kahlo pintando La mesa herida México 1940) oTurner/Océano

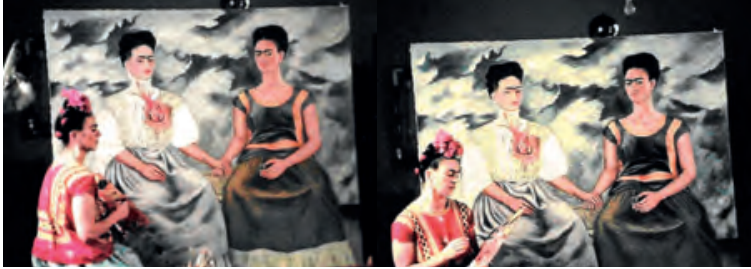

Imagen 10

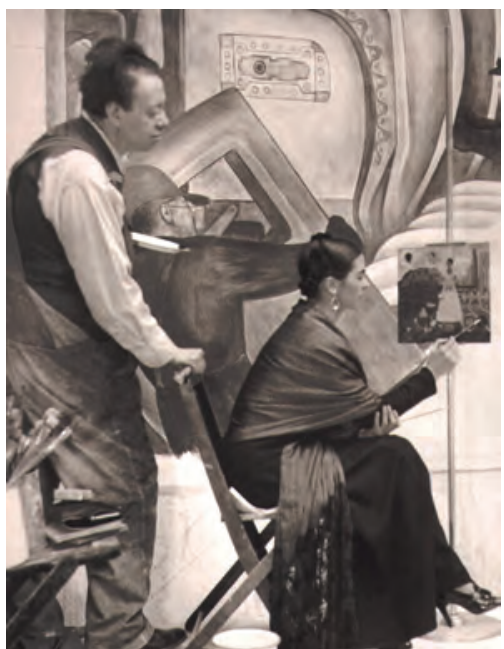

Imagen 9

(anónimo, Detroit c. 1933) @Turner/Océano

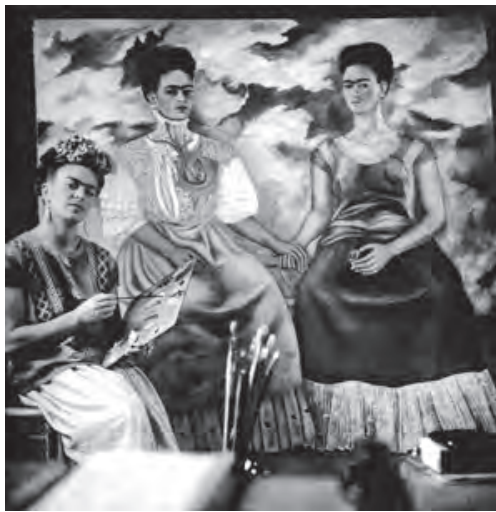

Imagen 11

(Ambas de N. Muray, Frida pintando las dos Fridas. Coyoacán 1938 ó 1939) @Turner/Océano 


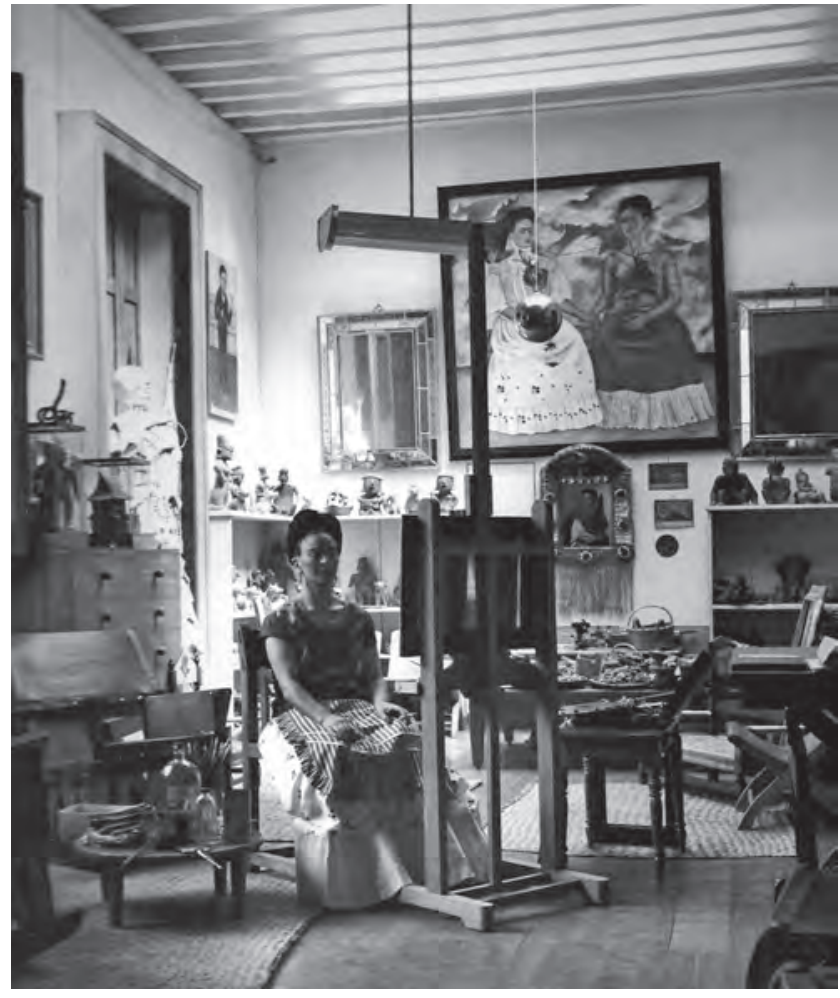

Imagen 12

(de Fritz Henle, Frida en su estudio, ca. 1943) @Turner/Océano

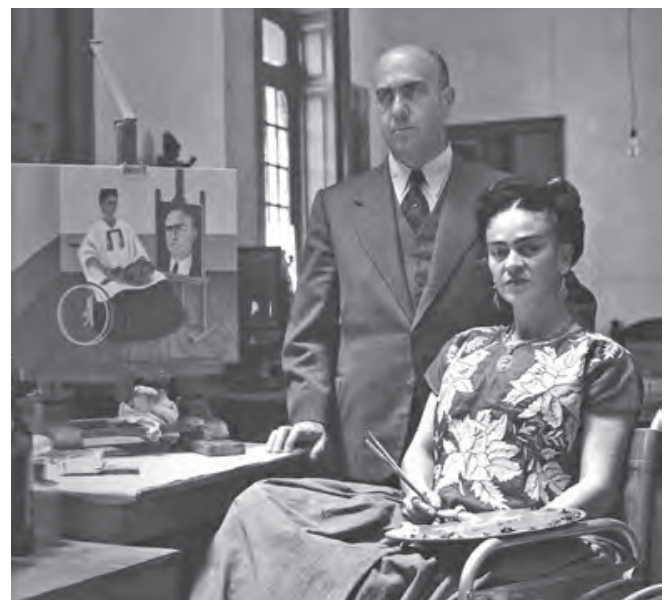

Imagen 13

(G. Freund, F.K. con el doctor Farill y su retrato, México 1951) ๑ VG Bild-Kunst, Bonn 2011

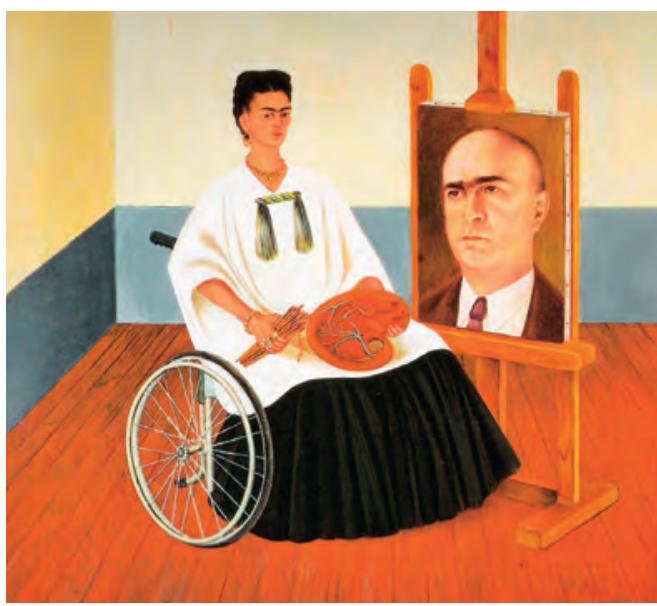

Imagen 14

(de F.K.: Autorretrato con el retrato del Dr. Farill, 1951) oTurner/Océano 
Quisiéramos describir con algo más de atención las imágenes 12 a 14. Ellas nos presentan un complejo sistema de estructuras que juega con duplicaciones y superposiciones de la mirada. Un fenómeno que se impone es la reciprocidad e interacción de las miradas, sean éstas de la pintora Kahlo o de la imagen-objeto-Kahlo, con la del observador o espectador. Kahlo se transforma en automodelo y nos transforma en modelo de sus pinturas, de cualquier modo en un activo espectador. Particular es la inestabilidad de la mirada que produce un juego de metamorfosis que se ubica entre el modelo, la pintura y el espectador y que tiene como efecto una serie de relaciones nómadas.

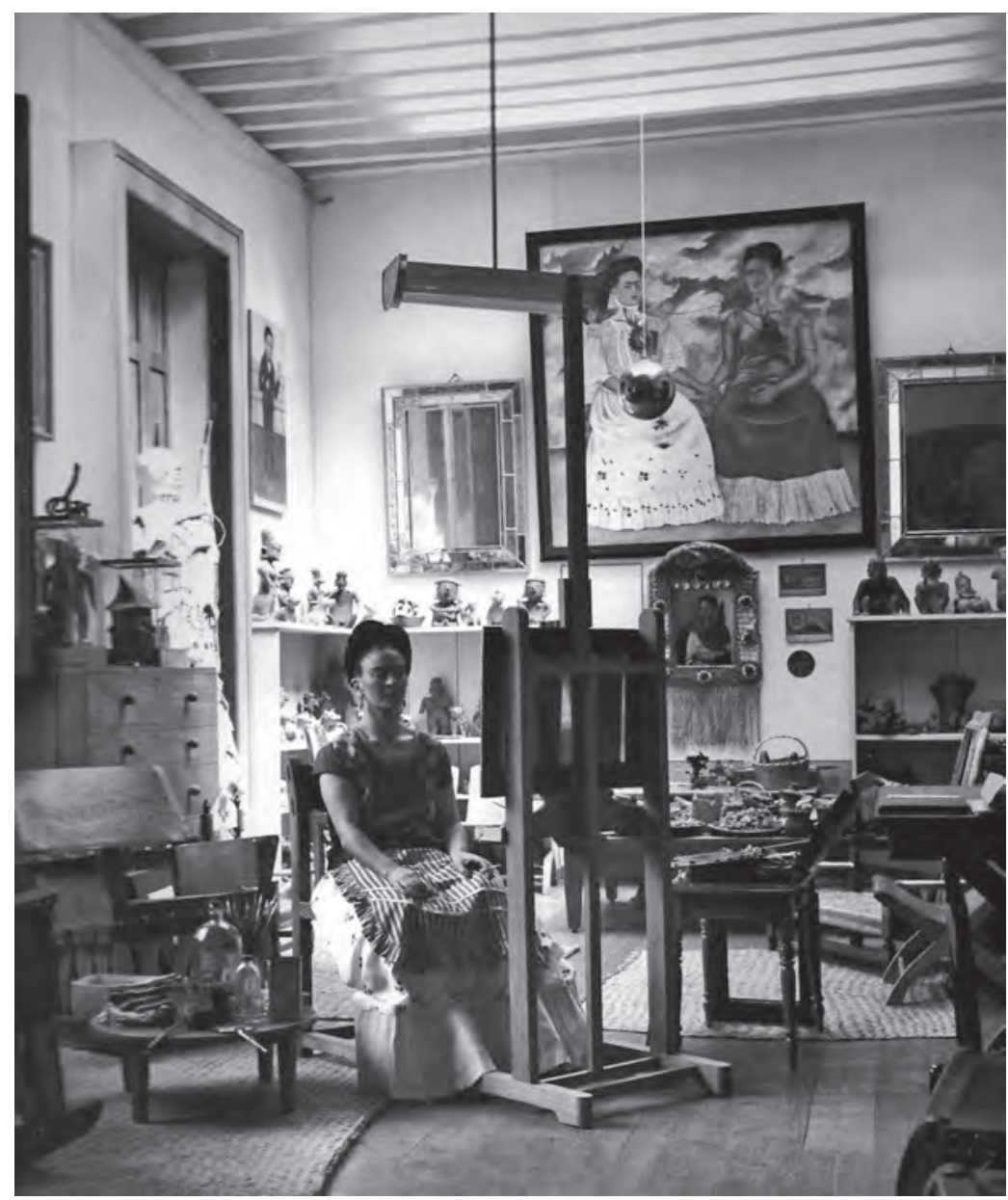

Imagen 12

(de Fritz Henle, Frida en su estudio, ca. 1943) @Turner/Océano

En esta foto, que quisiera llamar las «nuevas meninas» o «bienvenido Foucault», vemos cómo el fotógrafo nos ofrece una serie de puntos deambulantes. La luz de la lámpara sobre el atril no ilumina a Kahlo, sino que la encubre en una semioscuridad. Está en un momento de pausa fumando un cigarrillo. 
Por el contrario, la luz invade el ángulo izquierdo del atelier, poniendo en relieve una serie de objetos conocidos que quisiera denominar picto-generadores, como el esqueleto que habíamos ya encontrado sobre el baldaquín en otras pinturas (por ejemplo imagen 8 de la misma serie), figuras precolombinas y el espejo que, por el contrario del de «Las Meninas» de Velázquez, no nos revela el motivo del lienzo de Kahlo, sino tan sólo los contrastes de luz y sombra que marcan la foto en su totalidad. La luz cae en todo caso sobre la parte izquierda de su vestido blanco con ornamentos y lo relaciona así con el vestido de Kahlo en el cuadro colgado en la pared de las «Dos Fridas». La parte derecha de la Frida sentada es oscura y se conecta así con la Frida más oscura a la derecha del cuadro. De esa forma, tenemos una triplicación, ya cuadruplicación del modelo Kahlo: ésta transforma a Frida en el modelo de «Dos Fridas» sobre el lienzo, luego debajo del lienzo se encuentra el modelo Frida, la foto de Muray con el retazo rojo que se ha transformado a su vez en pintura por el marco barroco en que está enmarcado y Frida sentada transformada en modelo a su vez.

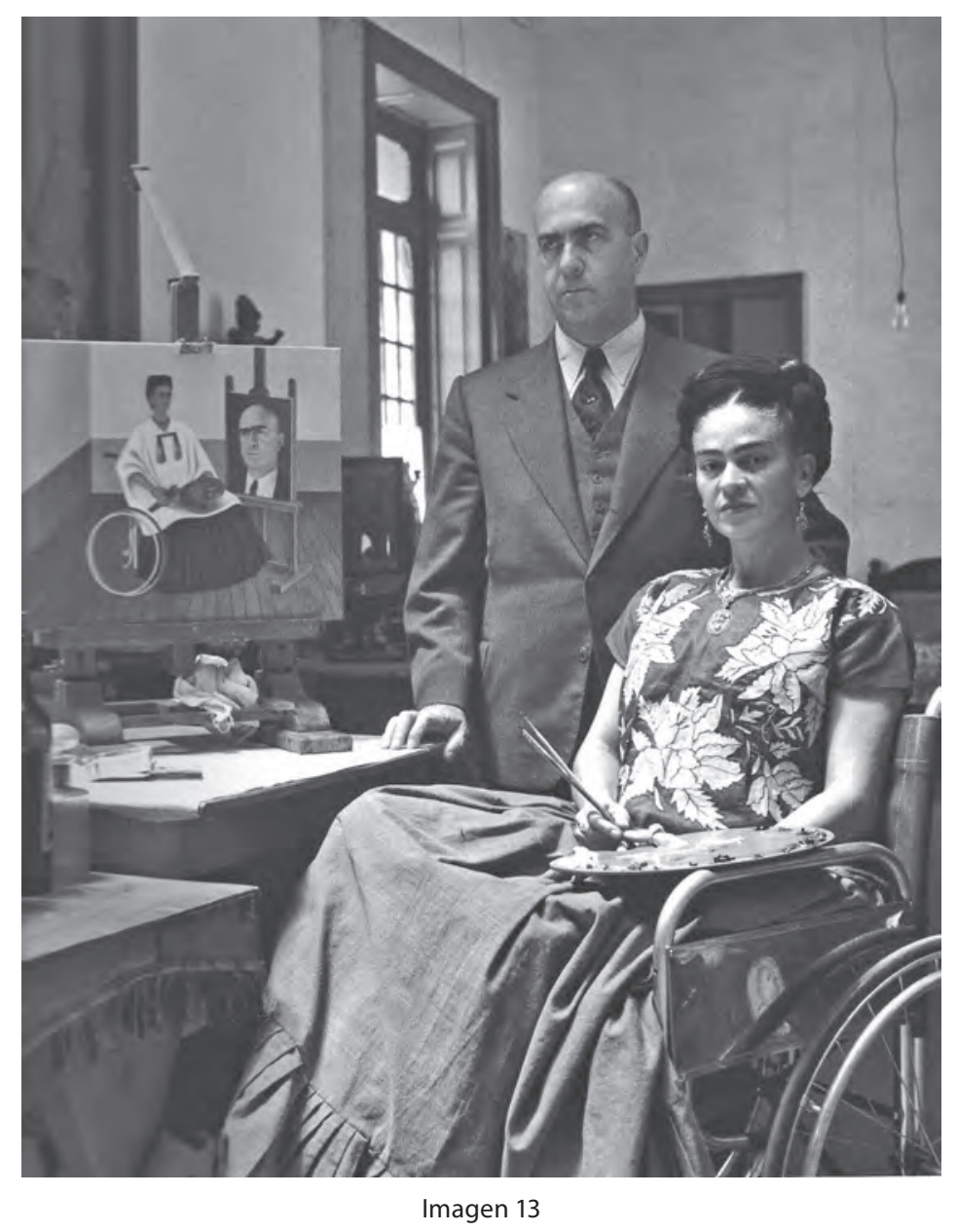

(G. Freund, F.K. con el doctor

Farill y su retrato, México 1951) @Turner/Océano 


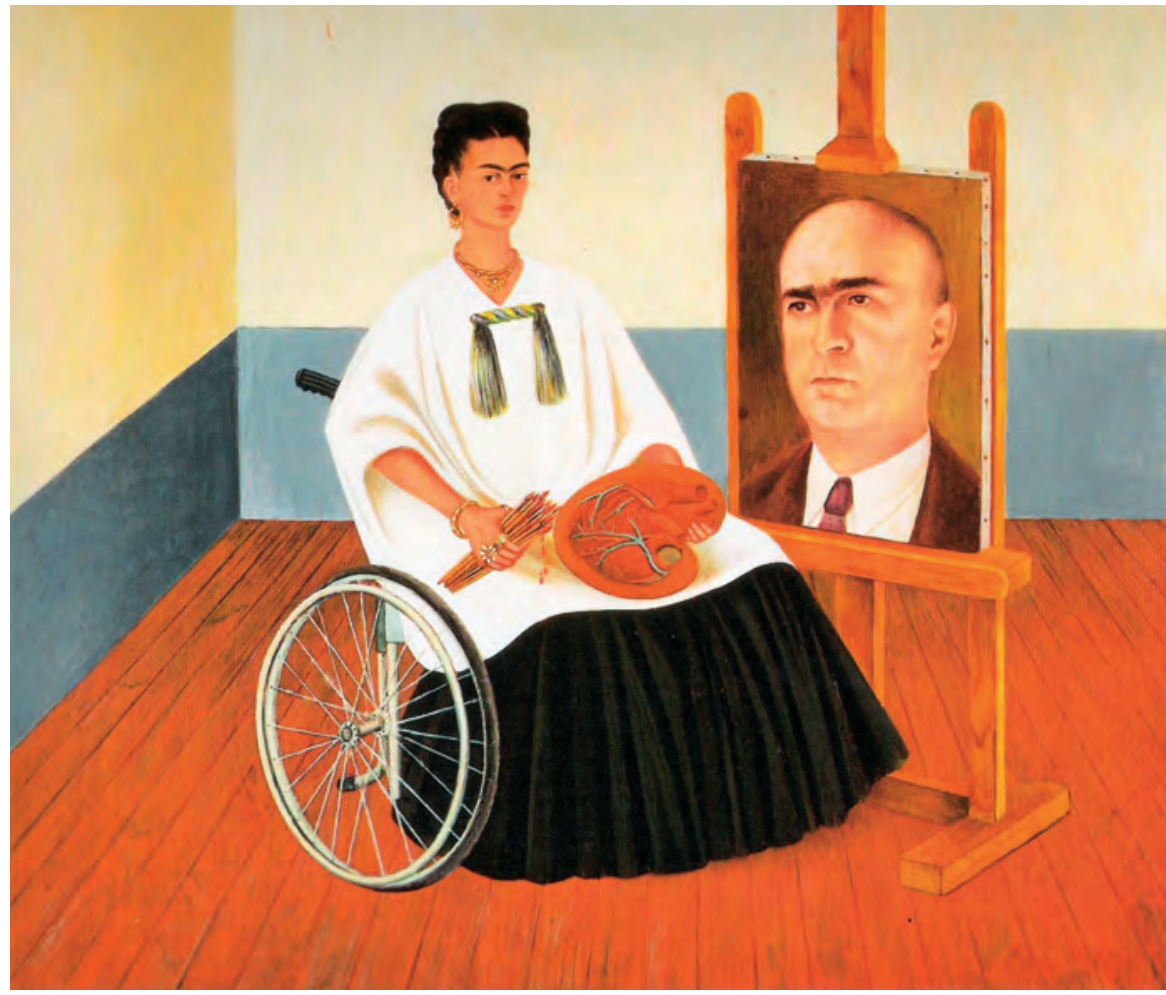

Imagen 14

(de F.K.: Autorretrato con el retrato del Dr. Farill 1951)

(c) VG Bild-Kunst, Bonn 2011

\section{CONCLUSIONES}

Esperamos haber demostrado, al menos como hipótesis de trabajo, que la complejidad de la obra de Kahlo no permite analizarla e interpretarla exhaustivamente partiendo de su biografía, de su accidente o de su relación amorosa con Diego y otras personas.

Además, hemos querido proponer investigar su obra con un Gesamtkunstwerk, donde tanto su Diario, como sus cartas, pinturas y fotografías forman un conjunto inseparable de múltiples metamorfosis, máscaras, escenificaciones. Con ello Kahlo pasa a ser una de las primeras personalidades artísticas de lo que luego se va a llamar performance, hapenning o fluxus.

Tenemos una performadora altamente reflexiva, que por una parte acentúa el momento único irrepetible, finito, efímero del arte, ese coup de main del que habla Artaud, y por otra trata de sujetar ese momento insujetable a través de la repetición: lugar privilegiado del deseo y de la circulación de la significación. 


\section{REFERENCIAS}

Adlung, Philipp. "Grußwort». Frida Kablo. Ausstellung und Katalog. Ed. Ortud Westheider y otros. München: Hirmer, 2006. 7. Medio impreso.

Artaud, Antonin. Van Gogh le suicidé de la société. Antonin Artaud: Euvres Complètes. Vol. XIII. París: Gallimard, 1974. Medio impreso.

Bark, Karlheinz (Ed.). Aisthesis. Wahrnehmung heute oder Perspektiven einer anderen Ästhetik. Leipzig: Reclam, 1990. Medio impreso.

Barthes, Roland. Le plaisir du texte. París: Seuil, 1973. Medio impreso. . La chambre claire. Notes sur la photographie. París: Gallimard/Seuil, 1980. Medio impreso.

Benjamin, Walter. Das Passagen-Werk. Vol. I./II. Frankfurt: Suhrkamp, 1983. Medio impreso.

Berringer, Johannes. «Erschöpfter Raum-Verschwundene Körper». Digitaler Schein. Ästhetik der elektronischen Medien. Ed. Florian Rötzer. Frankfurt: Suhrkamp, 1991. 491-518. Medio impreso.

. «A border Theory (Video/Performance)». Performing Arts Journal 39 (1991). 5484. Medio impreso.

Büscher, Barbara. «Theater und Elektronische Medien. Intermediale Praktiken in den siebziger und achtziger Jahren. Zeitgenössische Fragestellungen für die Theaterwissenschaft». Arbeitsfelder der Theaterwissenschaft. Ed. Erika Fischer-Lichte, Wolfgang Greisenegger, Hans-Thies Lehmann. Tübingen: Narr, 1994. Medio impreso.

Ceballos, René. «Frida: construcción iconográfica de un universo autorreferencial». Frida Kablo. Körper, Gender, Performance. Ed. Uta Felten y Tanja Schwan. Berlín: Tranvía, 2008. 155-167. Medio impreso.

Deleuze, Gilles. Différence et répétition. París: Presses Universitaires de France, 1968. Medio impreso.

. Francis Bacon - Logique de la sensation. París: La Différence, 1984. Medio impreso. . Le pli. Leibniz et le baroque. París: Minuit, 1988. Medio impreso.

De Man, Paul. «Autobiography as Defacement». MLN 94 (1979). 919-30. Medio impreso.

Barson, Tanya y Emma Dexter. Frida Kablo. Katalog Tate Modern. London: Schirmer/ Mosel, 2005. Medio impreso.

Felten, Uta. «Este, que ves, engaño colorido» - Intermedialität und hybride Diskurspraxis in der mexikanischen Literatur- und Mediengeschichte». Spielformen der Intermedialität im lateinamerikanischen Surrealismus. Ed. Uta Felten y Volker Roloff. Bielefeld: Transcript, 2004. 253-271. Medio impreso.

Felten, Uta y Tanja Schwan (Eds.). Frida Kahlo. Körper, Gender, Performance. Berlín: Tranvía, 2008. Medio impreso.

Frida Kablo. 100 Años del nacimiento de Frida Kablo. México: Océano/Landucci, 2007. Medio impreso.

Fuentes, Carlos. «Introducción». El diario de Frida Kablo. Un intimo autorretrato. Santa Fe de Bogotá: Norma, 1995. 7-24. Medio impreso.

Gronemann, Claudia. "(Autofiktionale) Inszenierungen von Hybridität und Androgynie: Transmediale und transkulturelle Strategien im 〈Diario» von Frida Kahlo». Frida 
Kablo. Körper, Gender, Performance. Ed. Uta Felten y Tanja Schwan. Berlín: Tranvía, 2008. 53-77. Medio impreso.

- «Escenificaciones híbridas: La escritura transmedial y transcultural en el Diario de Frida Kahlo». Mujeres en el umbral. De la iniciación femenina en las escritoras hispánicas. Ed. Emilia Perassi y Susana Regazzoni. Madrid: Renacimiento, 2006. 64-81. Medio impreso.

Hansen-Löve, Aage A. «Intermedialität und Intertextualität. Probleme der Korrelation von Wort- und Bildkunst - Am Beispiel der russischen Moderne». Dialog der Texte. Hamburger Kolloquium zur Intertextualität. Ed. Wolf Schmid y Wolf-Dieter Stempel. Wien: Instituto de Eslavística de la Universidad de Viena, 1983. 291-360. Medio impreso.

Herrera, Hayden. Frida: Una biografía de Frida Kablo. México: Diana, 2005. Medio impreso.

. Frida Kablo: die Gemälde. München: Schirmer/Mosel, 1997. Medio impreso.

Hess-Lüttich, Ernst W. B. (Ed.). Multimedial Communication. Semiotic Problems of its Notation. Tübingen: Narr, 1982. Medio impreso.

- «Multimediale Kommunikation als Realität des Theaters in theoriegeschichtlicher und systematischer Perspektive». Zeichen und Realität. Akten des 3. Semiologischen Kolloquiums Hamburg. Vol. III. Ed. Klaus Oehler. Tübingen: Stauffenburg, 1984. 915-27. Medio impreso.

Hoesterey, Ingeborg. Verschlungene Schriftzeichen. Intertextualität von Literatur und Kunst in der Moderne/Postmoderne. Frankfurt: Athenäum, 1988. Medio impreso.

Hooks, Margaret. Frida Kahlo, la gran ocultadora. New York/México: Turner/ Océano/ Throckmorton, Fine Art, 2002. Medio impreso.

Kahlo, Frida. El diario de Frida Kablo. Un intimo autorretrato. Santa Fe de Bogotá: Norma, 1995. Medio impreso.

Kröll, Katrin. «Körperbegabung versus Verkörperung. Das Verhältnis von Körper und Geist im frühneunzeitlichen Jahrmarktspektakel». Verkörperung. Ed. Erika FischerLichte, Christian Horn y Matthias Warstat. Tübingen/Basel: Francke, 2001. 91-110. Medio impreso.

Kroll, Renate. «Yo nunca he pintado sueños. He pintado mi realidad». Zum Mal- und Tagebuch der Frida Kahlo». Esta locura por los sueños... Traumdiskurs und Intermedialität in der romanischen Literatur-und Mediengeschichte. Ed. Uta Felten et al. Heidelberg: Schmidt, 2006. 277-93. Medio impreso.

. Blicke die ich sage. Frida Kahlo. Das Mal-und Tagebuch. Berlín: Reimer, 2007. Medio impreso.

Lowe, Sahra M. "Ensayo». El diario de Frida Kablo. Un intimo autorretrato. Santa Fe de Bogotá: Norma, 1995. 25-29. Medio impreso.

. «Transcripción del Diario con comentarios». El diario de Frida Kablo. Un íntimo autorretrato. Santa Fe de Bogotá: Norma, 1995. 201-287. Medio impreso.

Lyotard, Jean-François. Dérive à partir de Marx et Freud. París: Union Générale d'Éditions, 1973. Medio impreso.

López-Caparrós, Beatriz. Frida Kablo. Viva México. Text und Zeichnungen Willi Blöß; Colorierung. Aachen: Willi Blöß, 2004. Medio impreso.

Müller, Jürgen. «Für eine Forschungsperspektive der Intermedialität». Intermedialität. Münster: Nodus Publikationen, 1996. 80-92. Medio impreso. 
. Intermedialität. Formen moderner kultureller Kommunikation. Münster: Nodus Publikationen, 1996. Medio impreso.

Prignitz-Poda, Helga (Ed.). Frida Kablo. Die Malerin und ibr Werk. München: Schirmer/Mosel, 2004. Medio impreso.

Prümm, Karl. «Multimedialität und Intermedialität». Theaterzeitschrift 22: IV (1987). 95-103. Medio impreso.

Schuchardt, Beatrice. "Surrealism goes Hollywood. Hybridität wider Willen in Julie Taymors Frida». Manuscrito de Conferencia dictada el 20 del 7 del 2007 en el VI Forschungstreffens Lateinamerika/Iberische Halbinsel, en Leipzig, realizado por el Centro Iberoamericano de Investigación de Leipzig, 2007. Medio impreso.

Schwan, Tanja. Geschlechterperformanzen im historischen Umbruch: Renaissance und Avantgarde. Exemplarische Stationen der romanischen Literatur- und Kulturgeschichte. Manuscrito, 2009. Medio impreso.

Sklovskij, Viktor. «Der Zusammenhang zwischen den Verfahren der Sujetfügung und den allgemeinen Stilverfahren». Russischer Formalismus. Ed. Juri Striedter. München: Fink, 1971. 37-121. Medio impreso.

. «Die Kunst als Verfahren». Russischer Formalismus. Ed. Juri Striedter. München: Fink, 1971b. Medio impreso.

Toro, Alfonso de. «Frida Kahlo y las vanguardias europeas: Transpictorialidad-Transmedialidad». Aisthesis 43 (2008). 101-131. Medio impreso.

. «Reflexiones sobre fundamentos de investigación transdisciplinaria, transcultural y transtextual en las ciencias del teatro en el contexto de una teoría postmoderna y postcolonial de la hibridez e inter-medialidad». Gestos 32 (2001). 11-46. Medio impreso.

. «Hyperspektakularität〉/〈Hyperrealität〉/〈veristischer Surrealismus〉. Verkörperungen/ Entkörperungen: Transmediale und hybride Prothesen-Theater: Periférico de Objetos: Monteverdi Método Bélico». Spielformen der Intermedialitätt im spanischen und lateinamerikanischen Surrealismus. Ed. Uta Felten y Volker Roloff. Bielefeld: Transcript, 2004. 317-56. Medio impreso.

Westheider, Ortrud. «Frida Kahlo und die Avantgarde in Europa. Pittura Metafisica. Dadaismus, Neue Sachlichkeit und Surrealismus». Frida Kablo. Ausstellung und Katalog. Ed. Ortud Westheider y otros. München: Hirmer, 2006. Medio impreso.

Recepción: 23 de junio de 2011 Aceptación: 5 de octubre de 2011 